\title{
Photosynthetic Metabolism under Stressful Growth Conditions as a Bases for Crop Breeding and Yield Improvement
}

\author{
Fermín Morales 1,2, María Ancín ${ }^{1}$, Dorra Fakhet ${ }^{1}$, Jon González-Torralba ${ }^{3}$, Angie L. Gámez ${ }^{1}$, \\ Amaia Seminario ${ }^{1}$, David Soba ${ }^{1}$, Sinda Ben Mariem ${ }^{1}\left(\mathbb{D}\right.$, Miguel Garriga ${ }^{4}$ and \\ Iker Aranjuelo ${ }^{1, *(\mathbb{D})}$
}

1 Instituto de Agrobiotecnología (IdAB), Consejo Superior de Investigaciones Científicas (CSIC)-Gobierno de Navarra, Av. Pamplona 123, 31192 Mutilva, Spain; fmorales@eead.csic.es (F.M.); maria.ancin@unavarra.es (M.A.); fakhet.dorra@hotmail.fr (D.F.); angie-421@hotmail.com (A.L.G.); amaia.seminario@unavarra.es (A.S.); david.soba@unavarra.es (D.S.); sinda.ben@csic.es (S.B.M.)

2 Dpto. Nutrición Vegetal, Estación Experimental de Aula Dei (EEAD), CSIC, Apdo. 13034, 50080 Zaragoza, Spain

3 Institute for Multidisciplinary Applied Biology, Dpto. Agronomía, Biotecnología y Alimentación, Universidad Pública de Navarra, Campus Arrosadia, 31006 Pamplona, Spain; jon.gonzalez@unavarra.es

4 Centro de Mejoramiento Genético y Fenómica Vegetal, Facultad de Ciencias Agrarias, Universidad de Talca, Talca 3460000, Chile; miguel.garriga@gmail.com

* Correspondence: iker.aranjuelo@csic.es

Received: 29 November 2019; Accepted: 2 January 2020; Published: 10 January 2020

\begin{abstract}
Increased periods of water shortage and higher temperatures, together with a reduction in nutrient availability, have been proposed as major factors that negatively impact plant development. Photosynthetic $\mathrm{CO}_{2}$ assimilation is the basis of crop production for animal and human food, and for this reason, it has been selected as a primary target for crop phenotyping/breeding studies. Within this context, knowledge of the mechanisms involved in the response and acclimation of photosynthetic $\mathrm{CO}_{2}$ assimilation to multiple changing environmental conditions (including nutrients, water availability, and rising temperature) is a matter of great concern for the understanding of plant behavior under stress conditions, and for the development of new strategies and tools for enhancing plant growth in the future. The current review aims to analyze, from a multi-perspective approach (ranging across breeding, gas exchange, genomics, etc.) the impact of changing environmental conditions on the performance of the photosynthetic apparatus and, consequently, plant growth.
\end{abstract}

Keywords: climate change; crops; gas exchange; growth; photosynthesis; yield

\section{An Introduction to Climate Change and Crop Yield}

The global population is forecast to increase by 2 billion and reach 9.8 billion people in 2050 [1]. This means that it is mandatory to raise crop productivity by $70 \%$ to meet the projected demand by the middle of the century [2]. Food quality should also be taken into account because it must provide all the essential nutrients to maintain human health. Alongside the increase in population, changes in the diet, particularly due to the higher meat consumption in some developing countries, may exacerbate the demand for feed crops.

Abiotic environmental stresses are considered as major limitations threatening worldwide food security and have a great impact on global crop production. It has been proven that the impact of these changes on natural systems and human health has already been harmful. It is reported that the global mean land and ocean surface temperatures have increased by $0.8^{\circ} \mathrm{C}$ during the period 1888 to 2012 [3,4]. Further, although 
some degree of uncertainty exists in how the global surface temperature will rise, worldwide averaged surface temperature is foreseen to increase by 1.4 to $5.8^{\circ} \mathrm{C}$ by 2100 [3]. In addition, extreme heat events have been detected since 1950, and it is assumed that such extreme events are going to occur often in the future $[4,5]$. In fact, heat waves are projected to be more intense and longer-lasting, while cold episodes are projected to decrease significantly. Such changes are projected to occur almost everywhere [6].

Concurrent with the elevation of ambient temperatures, increases in evaporation and reductions in precipitation rates are expected, while a growing inequality in the distribution of precipitation around the world will make water reserves increasingly scarce [4]. Uncertainty, even greater than that of temperature, is inherent in the Earth's water cycle. Projected geographical distribution of rainfall foresees increases in the north of Europe, a large part of Asia, north of North America, north-west of South America and center of Africa, and decreases in the south of Europe, Africa, Australia, North America, South America, north of Africa and north and east of South America [4] affecting, if confirmed, water availability in different parts of the world in different ways, and therefore, food production. In other words, climate warming will lead to increased high-temperature periods, drought periods, and floods [4,7]. Such changes in environmental conditions will induce considerable disequilibrium in crop production.

Elevated temperature has been described to cause faster crop development and thus to reduce crop duration, which is mainly associated with lower yields [8]. It has been reported by Schlenker and Roberts [9] that under climate change scenarios with a temperature rise of less than $1{ }^{\circ} \mathrm{C}$, crop productivity of maize and soybean will decrease by more than $50 \%$. Adding to that, Hatfield and Prueger [10] reported that warmer temperatures mainly impacted the reproductive stage of maize development, and grain yield was significantly reduced by as much as $80 \%-90 \%$ with respect to normal temperature regimes. Besides, increasing temperatures adversely affect plant growth and development, which could affect wheat productivity negatively. For each degree rise in temperature, wheat production is estimated to reduce by $6 \%$ [11]. Water availability is another factor that largely determines yield. According to Lesk et al. [12], globally, it is estimated that losses of cereal production amounting to 1820 million $\mathrm{kg}$ have been caused by droughts during the past four decades. In wheat crops, water deficits can diminish production by at least $60 \%$ [13]. Daryanto et al. [14] reported $40 \%$ and $60 \%$ yield losses in maize and bean, respectively, with $\approx 35 \%$ reduction in water; however, they indicated that the yield losses varied as a function of the phenological stage affected by drought. In general, for cereals (maize, wheat, and rice), the later phase of grain filling is more susceptible to drought than the vegetative stage [14,15]. Overall, a trend towards yield reduction is being observed despite the existence of breeding programs aimed at developing new genotypes that are more efficient under limiting conditions, and this reflects the combined impact of all environmental factors on crop production worldwide. While the impacts of individual stress factors have been investigated during recent decades, the interactions between them and among them have received (comparatively) less attention [16]. In fact, when increased atmospheric $\mathrm{CO}_{2}$ concentration is studied as a single factor, crop production tends to increase, but under field conditions, various stress factors can occur simultaneously, such as water scarcity and high temperature, which could mitigate the positive effect of high $\mathrm{CO}_{2}$ on plant yields. Obviously, crop yields are constrained by the environment during the crop growth period. Therefore, climate models could be helpful tools to predict trends in crop productivity under future climate scenarios [17].

In this review, we first address the photosynthetic metabolism under stress conditions, especially high temperature, water, and nutrients scarcity. We then describe major methods that have been used for photosynthesis-based breeding under the scenario of climate change. Finally, we discuss perspectives for crop breeding programs.

\section{Photosynthetic Metabolism under a Changing Environment}

Exposure to environmental stress induces numerous physiological reactions in plants. Among the key physiological changes are alterations in photosynthetic rates and assimilate translocation [18], changes in water uptake and evapotranspiration $[19,20]$, effects on nutrient uptake and translocation [21,22], 
modifications to antioxidant reactions [23,24] and programmed cell death [25], and altered gene expression and enzyme activity [26,27], all of which are the most frequently impacted processes under environmental stress conditions.

In general terms, stress-derived inhibitory effects on photosynthesis may be due to (i) limitations on $\mathrm{CO}_{2}$ diffusion factors and/or (ii) metabolic factors (Figure 1). There is considerable evidence that underlines stomatal closure as the main event in stress conditions [28-31]. The result of stomatal closure is a decrease in the sub-stomatal and chloroplast $\mathrm{CO}_{2}$ concentration ( $\mathrm{Ci}$ and $\mathrm{Cc}$, respectively), which produces a fall in the assimilation of $\mathrm{CO}_{2}$. On the other hand, when water stress is more severe, metabolic limitations occur [32]. Among the most widely considered of these are impacts on Calvin cycle enzyme activity (Rubisco, SBPase, etc.) and depleted availability of ATP and NADPH [33,34].

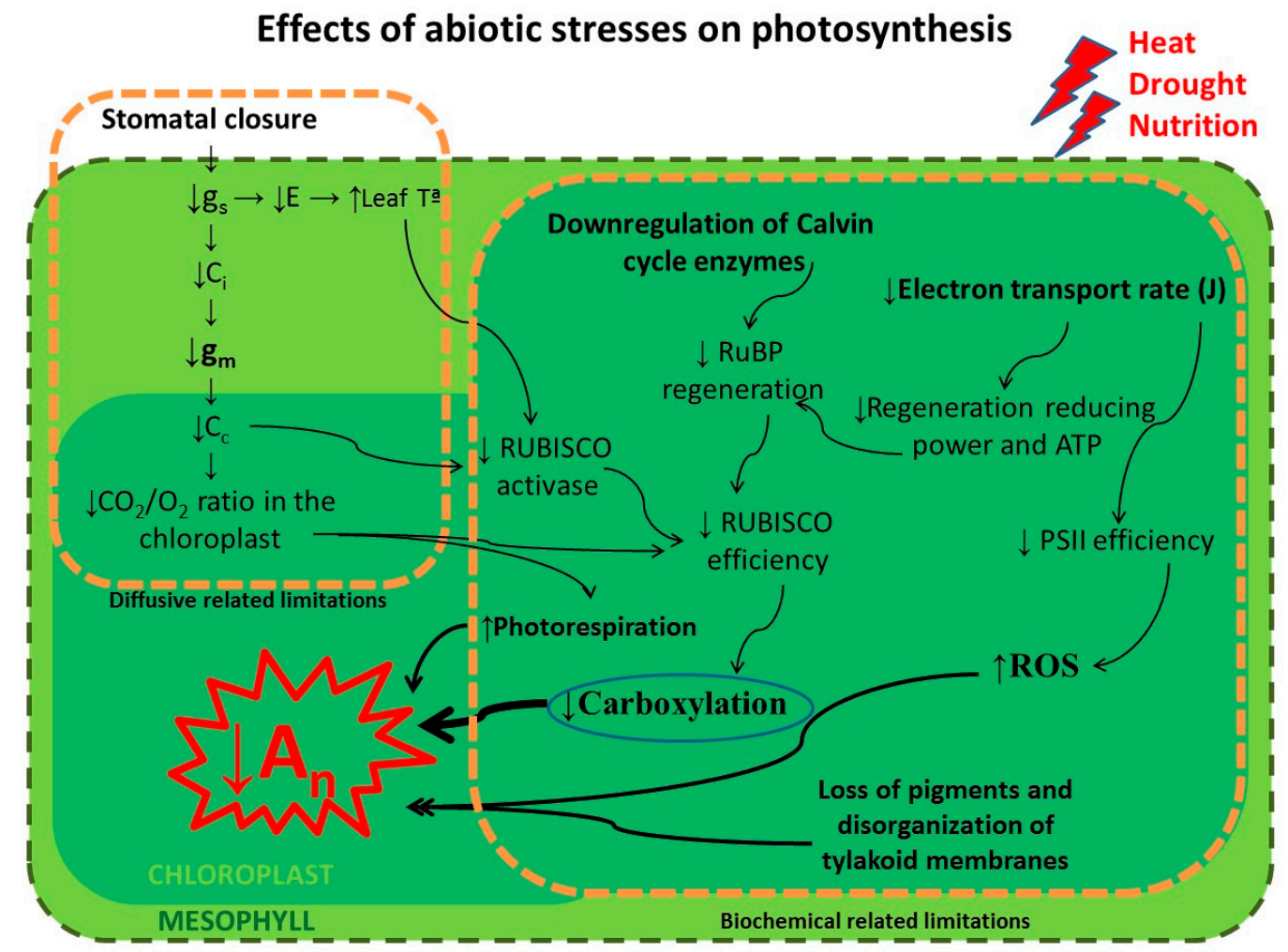

Figure 1. Photosynthetic metabolism under a changing environment. A multi-scale model representing the impact of key stress factors (high temperature, drought, and low soil fertilization levels) on photosynthetic performance associated with limitations to $\mathrm{CO}_{2}$ diffusion factors and/or metabolic factors. Stomatal closure diminishes sub-stomatal and chloroplast $\mathrm{CO}_{2}$ concentration $(\mathrm{Ci}$ and $\mathrm{Cc}$, respectively) with a consequent reduction in photosynthetic rates (An). Under severe stress conditions, limitations to the activity of Calvin cycle enzymes (Rubisco, SBPase, etc.) and the photosynthetic electron transport rate $(\mathrm{J})$, and the appearance of reactive oxygen species (ROS), among others, are observed.

\subsection{High Temperature}

Plant development and growth processes are predicted to be negatively affected by high temperatures in a climate change scenario. Faced with such an extreme global warming situation, carbon uptake by vegetation is clearly a major pathway for mitigating climate change [35,36]. Nevertheless, $\mathrm{CO}_{2}$ availability to plants can vary depending on the environmental conditions, and its assimilation is dependent on numerous factors; stomatal closure, changes in the activity of the Calvin cycle, or alterations in the thylakoid structure, among others $[37,38]$. Exposure of plants to high-temperature conditions results in well-documented changes at the biophysical and biochemical levels, thus limiting photosynthetic activity [39]. 
The effects of extreme high temperatures on crops have been widely analyzed in several species; wheat [40], cowpea [41], soybean [42], and rice [43]. In the case of wheat, Asseng et al. [44] provided a detailed impact assessment of high temperatures on yield and how critical the adverse effects will be on the production of this crop. Although most of these studies focus on the flowering stage, many evaluations have also been carried out on the other stages of plant development $[10,45,46]$. For example, Wang et al. [47] found differences in photosynthesis, the transpiration rate, and stomatal conductance values between pre-anthesis high temperature acclimated wheat plants and those that had not experienced pre-anthesis heat exposure. As Hay and Walker [48] described, crop yield is affected by heat stress due to temperature controlling the rate of plant metabolic processes. In this regard, many responses to heat stress have been identified in plants: growth inhibition, a seed establishment disability, a higher transpiration slowdown, a continued water loss, or a decrease in crop quality [49]. A decline in chlorophyll content is also one of the effects observed in plants exposed to high-temperature conditions, as described in cucumber and wheat [50], and it is due to a decrease in chlorophyll biosynthesis or acceleration of its degradation resulting from the destruction of enzymes involved in their biosynthesis [51].

In the first instance, extreme temperatures affect $\mathrm{CO}_{2}$ assimilation at the stomatal level, i.e., closure of stomata under heat stress conditions, and impaired photosynthesis is a consequence. In fact, by controlling water vapor and $\mathrm{CO}_{2}$ diffusion, stomata largely contribute to both the rate and the temperature dependence of photosynthesis [37]. Several studies have analyzed plant behavior at the stomatal conductance level under heat-stressed situations, with most indicating inhibition of photosynthesis [49,52-54]. Yang et al. [55] also suggested that stomatal responses to high temperature are strongly influenced by water vapor pressure in maize plants.

Another step in the $\mathrm{CO}_{2}$ diffusion pathway from the atmosphere to the site of carboxylation in chloroplasts is when $\mathrm{CO}_{2}$ molecules pass through leaf mesophyll, with mesophyll conductance (gm) being an important component that limits this diffusion [56]. These authors describe this parameter as dynamic, which could be related to differences between photosynthetic efficiency/capacity. Furthermore, gm is finite and measurable, and of similar magnitude as stomatal conductance $[57,58]$ and it varies between species [59] and in response to environmental variables, such as temperature [60]. Some authors have confirmed that gm is important because it explains a $40 \%$ decrease in $\mathrm{CO}_{2}$ concentration among atmosphere and carboxylation sites [61]. The data available in the literature indicate that gm exhibits a different pattern depending on the duration and the type of stress the plants experience [56]. In the case of extremely high temperatures, several authors have observed different responses in gm, from a decrease to a considerable increase or even constant values [60-64]. The work of von Caemmerer and Evans [65] confirms that the gm response might be one of the most temperature-dependent parameters in the biochemical model of photosynthetic rates. In this way, carbonic anhydrase and aquaporins have been proposed as key factors provoking structural changes in cell wall thus providing adaptive and acclimation responses which could explain the diversity in the temperature response of gm, $[56,66]$, an idea supported by work in rice and tobacco plants $[59,60,67,68]$. Crop productivity is determined by photosynthetic $\mathrm{CO}_{2}$ assimilation and respiration rates as both processes are temperature sensitive, although respiration is typically more sensitive than net photosynthesis to rising temperatures [69]. Temperature affects photosynthesis by influencing the electron transport capacity of the thylakoid membrane, together with its action on the kinetics of Rubisco and carboxylation efficiency [70]. As leaf temperature becomes higher, the photosynthetic rate increases, until decreasing after reaching optimum temperature, showing the effect of temperature on photosynthetic $\mathrm{CO}_{2}$ fixation, and $\mathrm{CO}_{2}$ release by photorespiration and mitochondrial respiration [71]. In C3 plants, Rubisco is the principal enzyme responsible for carbon assimilation, although it can also assimilate $\mathrm{O}_{2}$, which competes with $\mathrm{CO}_{2}$ for enzyme binding sites. As substrates of Rubisco, both $\mathrm{O}_{2}$ and $\mathrm{CO}_{2}$ play a key role in regulating the response of photosynthesis to heat stress [72], with the $\mathrm{CO}_{2}$ fixation rate of plants being affected by the $\mathrm{CO}_{2} / \mathrm{O}_{2}$ ratio. The increase in $\mathrm{CO}_{2}$ translates into an increase in the $\mathrm{CO}_{2} / \mathrm{O}_{2}$ ratio, which causes a decrease in photorespiration. However, elevated temperatures stimulate photorespiration 
due to greater solubility of $\mathrm{O}_{2}$ relative to $\mathrm{CO}_{2}$ [73], and decrease the specificity of Rubisco towards $\mathrm{CO}_{2}$ [74-76]. At the biochemical level, the heat lability of Rubisco activase could explain the limitation of photosynthetic activity under high temperatures, and this is because heat stress reduces the capacity of Rubisco activase to maintain the activation state of Rubisco [77,78]. Some studies have shown that Rubisco activity decreases when the temperature is raised as it does not allow a good balance between the activation/inactivation rates of Rubisco in cotton and tobacco plants [51,77]. However, in C4 maize plants, changes in the expression of a larger Rubisco subunit and limited recovery of the Rubisco activation state work as acclimation mechanisms [51]. Some studies have also shown that the photosynthetic parameter Vcmax (the maximum rate of Rubisco carboxylase activity) acts as a limiting factor on the rate of photosynthesis, having substantial roles in temperature acclimation [79], and it has been observed that generally, it increases as temperature rises to an optimal value and from there, it usually declines [80,81]. This decline in Vcmax under high temperatures is probably due to the dysfunction of Rubisco activase, resulting in a reduction in Rubisco activity. In addition, the principal element of the chloroplast electron transfer chain, PSII, may be damaged by elevated temperatures [82]. PSII is a heat-sensitive component of photosynthesis, and in addition to changes in the D1 protein and the plastoquinone pool, the influence of high temperature on photosynthetic components alters the energy distribution in PSII becoming oxidized. This could destabilize lipid-protein interactions, which could perturb the organization and function of PSII [49].

There is also a need that contributes to our understanding of the mechanisms by which plants adapt to heat stress. Because heat stress is considered an abiotic stress, several studies have focused on biochemical reactions, principally those related to hormones and primary and secondary metabolites, such as antioxidants [83]. At the molecular level, an alteration in the expression of genes leads to the synthesis of stress-related proteins, such as the activation of heat shock proteins (involved in signal transduction during heat stress), which are known to be an important adaptive strategy under this stress conditions [54].

Finally, not all plant species are able to cope with heat stress at the same level; plant sensitivity to high temperature varies according to the severity, duration, and developmental timing of the stress. However, all of them are forced to modulate their metabolism to prevent irreversible damage by reprogramming biological processes for stress adaptation [84]. For that reason, researchers are currently seeking to improve crop heat tolerance through the development of heat-tolerant genotypes via molecular breeding and genetic engineering $[85,86]$, even though these techniques are still very expensive and time-consuming.

\subsection{Water Stress}

An early initial response of plants, when faced with water deficit, is the alteration of plant water relations with decreases in leaf water potential of leaf, turgor pressure, relative water content (RWC), and transpiration rate (E) [15]. Due to their close relationship with turgor pressure, which represents the driving force for cell expansion [87], cell growth and leaf expansion are the most sensitive processes to drought $[88,89]$. Studies in crops, such as wheat, barley, and rice, have reported growth as being limited by drought [90-93].

In this sense, the response of plants to maintaining the cell water content is to limit water loss through fast stomatal closure $[87,88,94,95]$. For this reason, $\mathrm{CO}_{2}$ diffusion from the atmosphere to the sub-stomatal cavity is reduced, which results in a lower stomatal conductance $\left(\mathrm{g}_{\mathrm{s}}\right)$, and which in turn is the main cause of the decreases in the photosynthetic rate (A) under water stress [94]. Several studies have demonstrated decreases in $\mathrm{A}$ and $\mathrm{g}_{\mathrm{s}}$ in important crops under water deficit, such as wheat [92], rice [96], and grapevine [94]. Additionally, water use efficiency (WUE), which indicates the amount of biomass produced per unit of water used, is regulated mainly by $g_{s}$ [97] and under moderate water stress conditions it generally increases due to a lower $g_{s}$ and $E$, as shown in wheat $[98,99]$ and bean [100]. Nevertheless, under severe water scarcity, the WUE can decrease [101]. In general, stomatal conductance is more strongly affected and is regulated by endogenous abscisic acid (ABA) levels that 
trigger a cascade of signaling pathways and, consequently, an efflux of anion and $\mathrm{K}^{+}$from guard cells, which results in stomatal closure [95]. Studies in rice have demonstrated increases in ABA levels under lower water content, and the authors suggest that an increase in endogenous ABA is associated with mechanisms of drought escape [102].

The reduced $\mathrm{CO}_{2}$ diffusion through the stomata under water stress conditions is accompanied by a reduction in mesophyll conductance $\left(g_{m}\right)[56,88]$. As already stated, $g_{m}$ is defined as the $\mathrm{CO}_{2}$ diffusion to the site of carboxylation in the chloroplast through the leaf mesophyll. In addition, $g_{m}$ is considered an important factor in the regulation of photosynthesis under different environmental situations [68] due to a rapid response under stress conditions that is even greater than $g_{s}$. It exhibits a wide variability among species, functional groups, leaf forms, and developmental stages [56]. The reduced $g_{m}$ under water stress can be due to physical alterations in the intercellular spaces, biochemical changes, and/or membrane permeability [88], the latter apparently associated with expression and/or regulation of aquaporins [103]. Studies related to overexpression of the aquaporin NtAQP1 in tobacco plants result in a positive correlation with $g_{m}$ and photosynthesis [68]. Obviously, the $\mathrm{CO}_{2}$ concentration within the chloroplast $\left(C_{c}\right)$ is lower than in the sub-stomatal cavity $(C i)$, and this difference increases under water stress conditions [88].

Plants have developed interlinked strategies to overcome stress, and the biochemical responses are detected after a reduction in $\mathrm{CO}_{2}$ availability in the mesophyll [103]; among these, osmotic adjustment, osmoprotection, antioxidation, and scavenging defense systems have been reported as being important for drought tolerance [15]. Osmotic adjustment is considered an important mechanism to allow the maintenance of water uptake and cell turgor under stress conditions [88]. It consists of the overproduction of compatible solutes and ions, non-toxic in high concentrations, including soluble sugars, amino acids, organic acids, potassium ions, etc. [15]. Compounds such as proline, glutamine, and glycine-betaine can prevent protein denaturation and maintain them in native conformation at intermediate water content [104]. For instance, the enhancement of proline levels has been observed in maize, alfalfa, and wheat, and it has been associated with stress tolerance [105].

Water stress conditions also stimulate the production of reactive oxygen species (ROS), such as peroxide $\left(\mathrm{H}_{2} \mathrm{O}_{2}\right)$, superoxide $\left(\mathrm{O}_{2}{ }^{-}\right)$, and singlet oxygen $\left({ }^{1} \mathrm{O}_{2}\right)$, that cause membrane rupture and thereby affect photosynthesis $[87,95]$. However, in contrast to photosynthesis, plant respiration remains fairly constant during water stress, although mitochondrial electron transport is affected mainly through the alternative oxidase pathway, which maintains electron transport and prevents the formation of ROS [103]. The plant growth regulator, $\gamma$-aminobutyric acid, as well as free amino acids and sugars also play a role in scavenging ROS [15]. Other studies have shown an increase in the activity of scavenging enzymes, such as the enhancement of peroxidase activity under water deficit in durum wheat [106].

The plant response to water stress involves a complex of genes and processes regulated by interlinked genetic and biochemical mechanisms [87]. Changes in leaf biochemistry can result from the downregulation of photosynthetic metabolism machinery in response to a low supply of carbon substrate under prolonged water stress. In this way, several enzymes are downregulated or de-activated at low $\mathrm{CO}_{2}$ concentrations [88]. A decrease in the maximum velocity of carboxylation (Vcmax) indicates inhibition of Rubisco activity [103], as shown in plants of Medicago truncatula [100]. Other enzymes also decrease their activity, such as nitrate reductase [88]. In contrast, the production of antioxidant enzymes and stress-related proteins is upregulated under water stress [87].

In addition, water stress can activate cell-signaling pathways as an efficient response to environmental changes. The responses are triggered by secondary signal metabolites that include hormones (ABA, ethylene, cytokinins (CK)), ROS, and second messengers (sugars) [87,88]. Some findings indicate crosstalk among the ABA and CK hormones and the stress-signaling pathway. Within this pathway, redox signals act as regulatory agents where changes in the redox state regulate the expression of different genes related to photosynthesis. Furthermore, soluble sugars can be associated with hormones as part of the signaling network, and they tend to increase under water-scarcity conditions where they modify gene expression and proteomic patterns. Receptors and sensing proteins localized in membranes have a role in various signaling pathways [88]. 
Finally, as yield losses become more common under increasingly frequent and intense drought periods, the search is on for effective adaptation strategies to the effects of climate change on agriculture. It is, therefore, important to understand the responses and mechanisms by which plants can increase their adaptability to these adverse conditions. The approach should integrate photosynthesis responses, stomatal closure, osmotic adjustment, plant water relations, ROS scavenging and defense, and signaling and gene expression.

\subsection{Impoverished Soils}

Soil conditions determine leaf metabolism, and particularly photosynthetic metabolism [107]. Among those soil characteristics, it should be remarked the soil volume able to be explored by roots related to its compactness and soil physicochemical properties (nutrient and toxic elements composition and its capacity to hold and release water and nutrients). Soil nutrient availability and plant requirements vary greatly, depending on the nutrient type. Among the macronutrients, $\mathrm{N}$ (in the chemical forms of $\mathrm{NO}_{3}{ }^{-}$and $\mathrm{NH}_{4}{ }^{+}$) is one of the elements that plants need to absorb from the soil. N-unstressed plants have between $2 \%$ and $5 \%$ dry weight (DW) range of concentrations found in different plant tissues, crop developments, and species [108]. Soils contain large amounts of total $\mathrm{P}$, from which only the chemical forms $\mathrm{H}_{2} \mathrm{PO}_{4}{ }^{-}$and $\mathrm{HPO}_{4}{ }^{-2}$ are used by roots. Growth is not limited by $\mathrm{P}$ when the range in the plant tissues is between 0.3 and $0.5 \% \mathrm{DW}[108,109]$. Soil K content (mostly inorganic) is in the range of $0.3 \%$ to $3 \%$. Sandy soils can be problematic for growth, because of the high mobility of $\mathrm{K}$ in such soils, and the high demand that plants have for this mineral. Potassium is required by plants in amounts as high as 1-2\% DW [108], making it the most concentrated mono-charged cation in the cells. Among the micronutrients, $\mathrm{Fe}, \mathrm{Mn}, \mathrm{Cu}$, and $\mathrm{Zn}$ need to be highlighted. Soils with $\mathrm{Fe}$ contents of up to $3.2 \%$ are common [110]. However, in calcareous and alkaline soils, Fe occurs as oxides and hydroxides with very low solubility. At these high $\mathrm{pHs}$, the Fe atoms free in the soil are at a concentration of $10^{-10} \mathrm{M}$, while plant requirements are ca. $10^{-7} \mathrm{M}$ [111], causing Fe deficiency. Fe deficiency appears when Fe in the plant tissues drops below 50-150 $\mathrm{gg} \mathrm{g}^{-1} \mathrm{DW}$ [108]. Soils are generally quite rich in $\mathrm{Mn}$, but only the cation in the $\mathrm{Mn}^{+2}$ redox state is readily available to plants for root uptake. For different species and environmental variables, the threshold values for Mn deficiency are 10-20 $\mu \mathrm{g} \mathrm{g}^{-1} \mathrm{DW}$ [108]. In soils that have not been contaminated with $\mathrm{Cu}$, soils have contents in the range of 2 to $40 \mathrm{mg}$ per $\mathrm{kg}$. Plant roots absorb $\mathrm{Cu}$ as the divalent cation $\mathrm{Cu}^{+2}$ in well-oxygenated soils, or as $\mathrm{Cu}^{+}$under flooding or in poorly oxygenated soils. Leaf $\mathrm{Cu}$ deficiency usually appears below 3-5 $\mu \mathrm{g} \mathrm{g}^{-1}$ DW [108]. Soils non-contaminated by Zn have 10-80 $\mathrm{mg}$ of $\mathrm{Zn}$ per kilogram of soil. Plants absorb $\mathrm{Zn}$ as the divalent cation $\mathrm{Zn}^{2+}$, although the chemical form $\mathrm{ZnOH}^{+}$is possibly also absorbed in high $\mathrm{pH}$ soils [108]. The threshold for leaf $\mathrm{Zn}$ deficiency is 15-20 $\mu \mathrm{g}$ of Zn per gram DW [108].

In agricultural areas, plants require favorable soil compaction, optimal soil water content, and nutrients, because crops control growth and yield as a function of the edaphic conditions and the environment. Commonly, photosynthesis responds to those stresses slower than does growth. In compacted soils, under drought or in soils poor in nutrients, photosynthesis is impaired because of different factors [107]. In P-deficient leaves and under drought (the latter only in some species), chlorophyll (Chl) remains fairly constant. Under deficiency of $\mathrm{N}$ and $\mathrm{K}$, or of micronutrients, such as $\mathrm{Mn}, \mathrm{Fe}, \mathrm{Zn}$, and $\mathrm{Cu}$, however, $\mathrm{Chl}$ diminishes. Leaves with low content of $\mathrm{Chl}$ may or may not have low photosynthetic rates; only large decreases in $\mathrm{Chl}$ will have consequences in light gathering. In leaves affected by Fe deficiency, a curvilinear function is found between $\mathrm{Chl}$ and light absorption, linear at very low values of $\mathrm{Chl}$ and with small increases in light gathering at the highest $\mathrm{Chl}$ concentrations [112].

A low stomatal aperture limits photosynthesis under a variety of stress factors. Thus, it is commonly reported in response to drought and widely documented in compacted soil-grown plants or in those soils inducing the deficiencies of the macronutrients $\mathrm{K}$ and $\mathrm{P}$, and the micronutrients $\mathrm{Zn}$ and $\mathrm{Cu}$ [107]. When drawing conclusions about stomatal limitations to photosynthesis, based simply on low stomatal conductance or low transpiration rates, one must be wary. It is true that a low stomatal conductance will lead to low photosynthetic rates, but it is also true that low rates of 
photosynthesis, independent of the causes, will lead to elevated $\mathrm{CO}_{2}$ levels within the leaf mesophyll close to the sub-stomatal chamber, which will cause partial stomatal closure. In any of the two situations mentioned above, stomata close, but the stomata are only a part of the resistance that the leaf poses to the diffusion of $\mathrm{CO}_{2}$ from the atmosphere to the carboxylation sites in the chloroplast. Once the $\mathrm{CO}_{2}$ molecules cross the sub-stomatal cavity, they need to travel across the different layers of leaf cells, encountering different barriers, to reach the chloroplast Rubisco enzyme. Under drought and limiting $\mathrm{N}$ and $\mathrm{Mn}$, the mesophyll conductance to $\mathrm{CO}_{2}$ limits the photosynthetic rates [107]. An impaired photochemistry clearly limits $\mathrm{CO}_{2}$ fixation in leaves affected by Fe deficiency. Furthermore, this was documented from time to time with $\mathrm{K}$ deficiency [107]. In $\mathrm{N}$ - and K-deficient leaves, $\mathrm{C}$ fixation is limited by the cell biochemistry (Rubisco carboxylation activity, biochemical reactions within the Calvin-Benson cycle, and carbohydrate anabolism and transport), while it is not frequent in response to low water availability, soil compaction, or scarce amounts of micronutrients [107]. In plants grown in environmentally-controlled growth chambers and in the field with limiting $\mathrm{Fe}$, leaf light-gathering, PSII photochemical reactions, and Rubisco carboxylation co-limit photosynthesis, downregulating all of them coordinately $[113,114]$. Under some circumstances, such as plants deficient in K or micronutrients, there has been evidence of altered chloroplast ultrastructure and function. Further investigation is required to elucidate whether such changes are actually damage or might be alterations that evidence adaptation to the stress conditions (see 107 for a detailed discussion).

Plants in the field interact with many microorganisms that reach the leaves via the atmosphere and the roots via the soil. At the soil level, microbes (such as symbiotic ecto- and endomycorrhizal fungi, $\mathrm{N}$-fixing bacteria, and mutualistic microbes) are able to promote plant growth. Microbes act, moreover, as sinks for a part of the carbohydrates synthesized by the plant, enhancing, as a result, photosynthesis in the plants with which they interact. Soil compaction has been shown to impair American elm $\mathrm{CO}_{2}$ fixation in non-inoculated plants, whereas in symbiosis with ectomycorrhizal fungi, physiology, and, in consequence, growth was hardly affected [115]. Thus, symbiosis with ectomycorrhizal fungi can be advantageous in forest areas where human activities, fire, or other causes have compacted the soil [115]. In line with this, the symbiosis of ectomycorrhizal fungi with Populus cathayana improved electron transport and $\mathrm{CO}_{2}$ fixation rates, more markedly under low than under high water availability [116].

\section{Photosynthesis as a Strategy to Improve Crop Yield}

As mentioned before, the production of sufficient food to meet increasing population demands while maintaining environmental sustainability is one of the biggest challenges of the twenty-first century $[1,2]$. This has to be achieved despite increasingly variable weather patterns that are associated with global climate change.

Crop biomass production and yield are mainly derived from the cumulative $\mathrm{CO}_{2}$ assimilation rate during the growing season [117]. There is increasing evidence that to achieve a quantum boost to cereal crop yield potential, a major improvement in photosynthetic capacity and/or efficiency will be required [118]. Reynolds et al. [118] highlight the fact that, together with traits like optimizing partitioning to grain yield, the increase in photosynthetic capacity and efficiency (radiation use efficiency, RUE) can be a targeted approach to develop new germplasm better adapted to stressful growth conditions.

There is also evidence that historic gains in wheat yield potential have been associated with increased photosynthesis. Furthermore, basic research in photosynthesis has confirmed that substantial improvements are theoretically possible [119].

According to Passioura's identity [120], grain yield (GY) is determined by:

$$
\mathrm{GY}=\mathrm{LI} \times \mathrm{RUE} \times \mathrm{HI},
$$

where $\mathrm{LI}=$ light interception by the crop; RUE = radiation use efficiency, and $\mathrm{HI}=$ the harvest index (ratio of harvestable versus total aerial biomass) (Figure 2). Since the Green Revolution, yield potential has continued to increase mainly due to improvements in HI. Despite a hypothetical limit to HI of 0.62 in 
wheat, there has been no systematic progress since the early 1990s from values of $0.50-0.55$. Austin [121] predicted a maximum theoretical $\mathrm{HI}$ of 0.62 in winter wheat based on an extrapolation from the mean value (0.49) observed for the four most modern winter wheat cultivars characterized by Austin et al. [122] in the United Kingdom. These data indicate that the HI of two major food crops, wheat, and rice, is now approaching a plateau, and further increases in yield will necessitate an increase in productive biomass and, therefore, an increase in photosynthesis. The limited capacity to increase HI highlights RUE as a factor that needs to be further incorporated into breeding programs. Theoretical calculations reveal that wheat yield potential can be improved by up to $50 \%$ through the genetic improvement of RUE.

RUE is largely determined in cereal crops by the interception of light necessary for photosynthesis (especially after canopy closure) and the phenological stage. Thus, the angle adjustment of the leaf and canopy architecture has an important role in the photosynthesis and productivity of these crops [118,123,124]. Modern varieties of cereal crops (e.g., wheat, rice) have more erect leaves [124,125], facilitating the penetration of light into the lower layers of the canopy. It has been suggested that an ideal plant ideotype in cereals is one that has an increased leaf angle from the top to the basal layers of the canopy [126-128]. Cultivars with upright leaves have greater light interception capacity that translates into significant increases in photosynthesis, biomass production, and yield in major crops, such as corn [129-131], rice [132-134], and wheat [119,135].

The process of senescence in plants is genetically controlled and determined by environmental conditions. During senescence, the concentration of leaf chlorophyll decreases, and thus, as these decreases reach a given threshold, the leaf photosynthetic capacity decreases. Plants with delayed senescence or stay-green usually have a longer period of grain filling, greater accumulation of assimilated $\mathrm{CO}_{2}$ throughout the season, and higher yields [136,137]. Some studies have reported a close relationship between functional stay-green and tolerance to drought and heat stress [137-143]. It has been proposed that chloroplast ultrastructure regeneration and better performance of the antioxidant system are responsible for the functional "stay-green" phenotype [144-146]. Thus, functional stay-green could be useful to design crops suitable for stressful environmental conditions.

\section{YIELD = LI $\times$ RUE $\times$ HI}

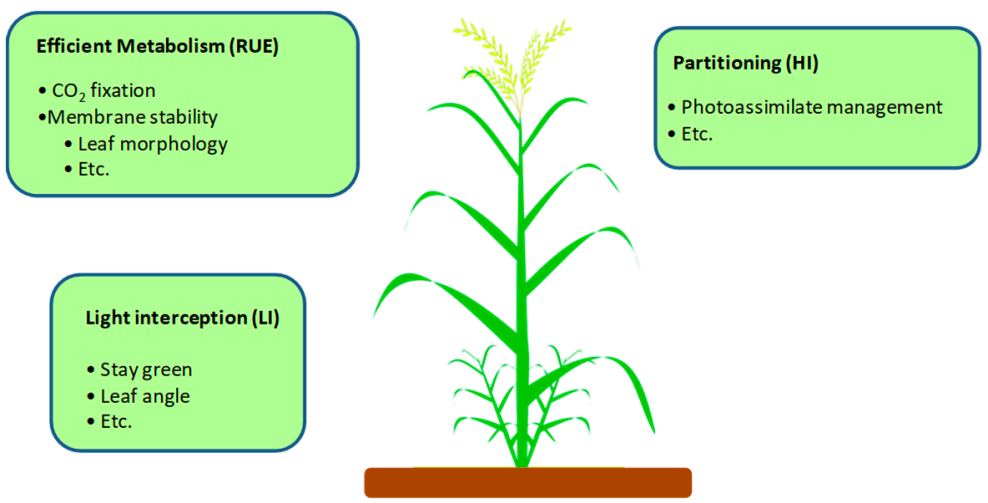

Figure 2. Photosynthesis as a strategy to improve crop yield. Grain yield improvement model developed by Passioura [120]. LI refers to light interception by the crop; RUE refers to radiation use efficiency, and HI refers to harvest index. Adapted from [147].

\section{Photosynthesis-Based Breeding under the Scenario of Global Climatic Change: Marker-Assisted Selection, Genomic Selection, and Genetic Engineering}

Photosynthesis is a quantitative trait that involves multiple genes, regulatory mechanisms, and different metabolic pathways and plant structures working together [148]. Several studies have identified possible traits to be addressed to increase the efficiency of $\mathrm{CO}_{2}$ assimilation in crops, 
either through traditional breeding or using modern techniques of synthetic biology and genetic engineering [117,149-153] (Figures 3 and 4).

Photosynthesis, and traits related to plant performance in general under abiotic stress, is complex and quantitative in nature $[154,155]$. Quantitative trait expression is controlled by many quantitative trait loci (QTLs), most of them with a small effect on the trait [156]. However, there is a significant natural variation in traits associated with photosynthesis in the available germplasm of major crops [117,153] that could be used for breeding purposes. In breeding programs, assessment of the genotypes is usually carried out under multiple environmental conditions to estimate the genotype $\times$ environment interactions necessary for selecting stable and high-performance phenotypes [157]. High throughput phenotyping (HTP) is a good example, being a successful combination of plant science, engineering, and computation for identifying and assessing plant traits that are key breading targets for crop improvements under stressful environments. Among the HTP techniques, remote sensing is currently the most widely used approach to evaluate these traits [158] (Figure 3). Remote sensing techniques can be summarized in five categories: (i) RGB cameras, (ii) spectral reflectance, (iii) thermal imaging, (iv) fluorescence imaging, and (v) active sensors (LiDAR and Radar). The advantage of HTP is that it can continuously provide a wide variety of crop information at different spatial scales. On the other hand, due to the enormous volume and variety of imaging and remote sensing data generated, one of the main limiting factors is the management and interpretation of all this information. Potent analysis and statistical tools are required, and improved software will be necessary to generate suitable data modeling that incorporates genotypic, phenotypic, and environmental variability so that this phenotyping bottleneck can be overcome and better crop breeding achieved for the stressed conditions projected for the future.

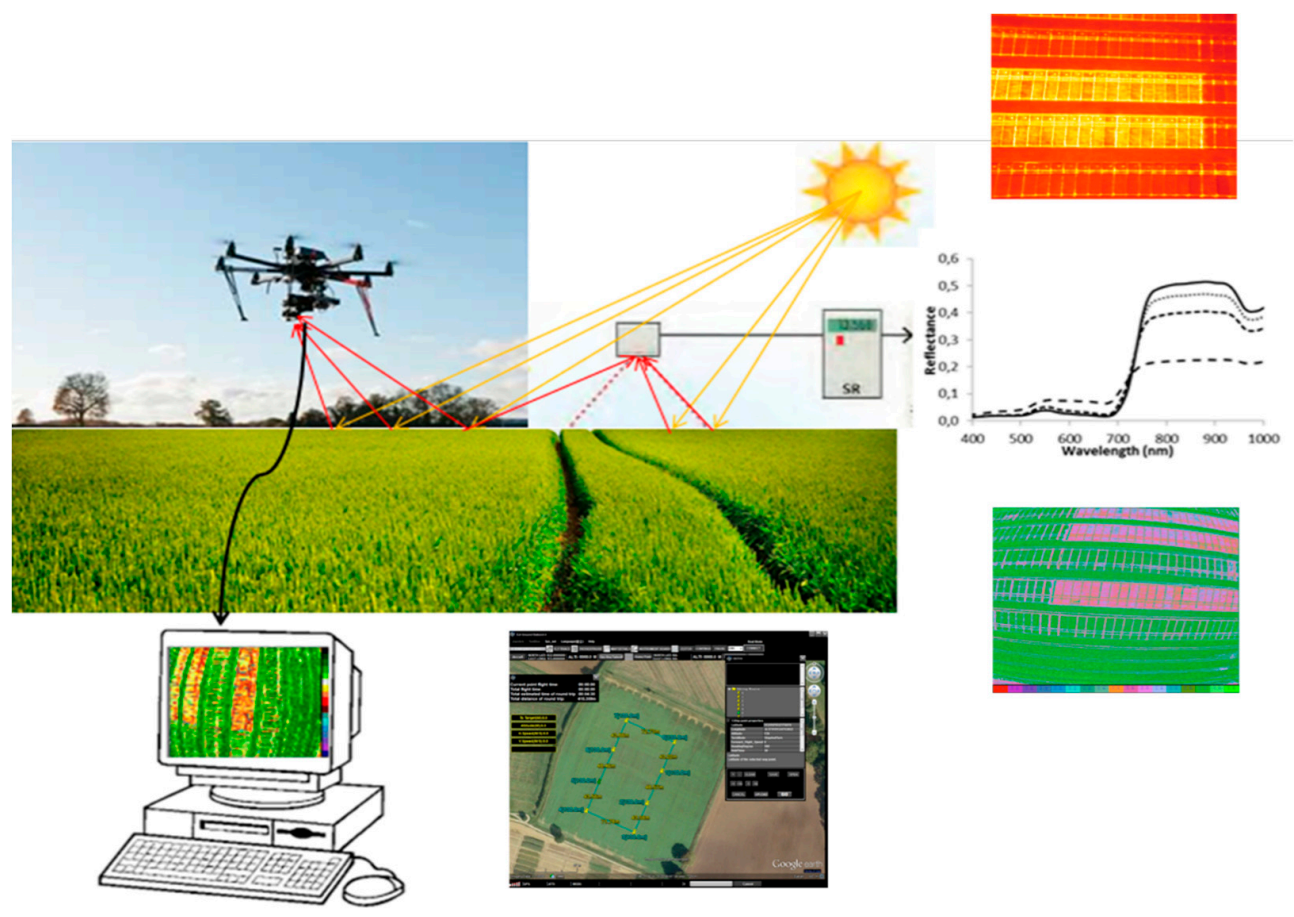

Figure 3. High throughput phenotyping using remote sensing. The production of sufficient food to meet increasing population demands while maintaining environmental sustainability is one of the greatest challenges of the twenty-first century. High throughput phenotyping (HTP) allows for precise monitoring of plant organs, individual plants, field plots, and full fields as required. These platforms include spectroradiometers, thermal sensors, Red-Green-Blue (RGB) imaging, etc. Due to the enormous volume and variety of imaging and remote sensing data generated, one of the main limiting factors is the management and interpretation of all this information. Further, connecting the different scales and platforms will be an important goal, and the key to creating useful phenotyping tools for the selection of genotypes with enhanced resource use efficiency under future stressful environments. 
An excellent introduction to QTL mapping and marker-assisted selection (MAS) for plant breeding has already been provided by Singh and Singh [159]. Indeed, QTLs for photosynthesis-related traits could be useful for MAS in breeding programs to obtain genotypes with improved $\mathrm{CO}_{2}$ assimilation and WUE. Several studies of QTL mapping of traits associated with $\mathrm{CO}_{2}$ assimilation have been conducted in major crops. As was previously discussed, $\mathrm{g}_{\mathrm{s}}$, canopy structure, and functional stay-green are among the most addressed traits studied to improve plant photosynthesis in crops. The relationship between QTLs and gs has been established in rice [160-162], wheat [163-166], barley [167,168], and sorghum [169], although a more in-depth mapping is required to enable the identification of genes directly related to the anatomy and functioning of the stomata. Changes in leaf angle and plant architecture are features of interest in cereal breeding programs [170,171]. Several QTLs related to leaf angle have been identified in maize and rice ([172] and references therein), bread wheat [173-175], and durum wheat [176], as well as genes associated with changes in leaf angle in maize, rice, and sorghum [172]. On the other hand, the association between QTLs and stay-green has been reported in wheat [137,143,177,178], maize [140,179-182], barley [141], sorghum [183-186], and rice [187]. In the same way, the association between chlorophyll content in the flag leaf and the magnitude of the net assimilation of $\mathrm{CO}_{2}$ has been reported, and QTLs for chlorophyll content and photosynthesis have been identified in rice [188], wheat [163,189], and barley [167,190]. These QTLs could be useful tools in MAS systems for improving photosynthesis under stressful conditions in these species. Although crop QTLs mentioned here are related to $g_{s}$, canopy structure, and stay-green due the nature of the $\mathrm{CO}_{2}$ assimilation process, QTLs associated with stress tolerance, such as productivity traits (grain yield and yield components) and physiological traits (e.g., stem reserve mobilization or water-soluble carbohydrates), are to some extent, also associated with photosynthesis.

In spite of the many studies and QTLs mapped in major crops, only a few have been used in practice for selection purposes in crop breeding programs, and those have been mostly restricted to traits with simple inheritance, such as monogenic or oligogenic inheritance including resistance to diseases and pests [191-193]. Among other factors, Jiang [194] stated that the low impact of MAS on crop breeding is due to (i) not all markers being applicable across populations due to lack of marker polymorphism or reliable marker-trait association, (ii) imprecise estimates of QTL locations and effects; (iii) a large number of breeding programs not being equipped with adequate facilities and conditions for large-scale adoption of MAS, (iv) MAS methods are not designed for large scale use in practical breeding programs, and (v) higher startup expenses and labor costs. Because of these limitations, and the development of next-generation sequencing (NGS) technologies that have allowed sequencing of genomes with high efficiency and decreasing costs, interest in the use of genomic selection (GS) tools has increased [195-197]. Genomic selection uses genome-wide markers (e.g., single nucleotide polymorphisms (SNPs)) and statistical models to predict the genomic breeding value of individuals in a breeding population [198-200]. Some examples of GS in plant breeding of maize, barley, wheat, rice, and oats for productivity and morphological traits, and disease resistance, are reviewed by Barabaschi et al. [201]. Nowadays, reference genomes for several important crop species (e.g., rice, wheat, barley, maize, and soybean) are available in public databases (http://www.gramene.org/; http://www.plantgdb.org/), and there are NGS-based platforms for genome-wide high-throughput genotyping for crop species $[195,197]$. Combining these with the accumulated information on QTL mapping, genome-wide association (GWAS) studies, and gene expression will all contribute to the consolidation of phenotype-associated genomic regions for crop breeding of quantitative traits [196].

Although GS is a promising approach to select parents in the early stages of the breeding process [195], the slow progress in high-throughput field phenotyping (HTFP) is limiting its implementation in breeding programs [157,202,203]. Well-designed phenotyping across multiple environments may provide more accurate estimates of QTL/gene locations and the effects necessary for efficient genomic selection [194]. High-throughput field phenotyping platforms capable of simultaneous assessment of traits of interest in dozens or hundreds of genotypes are currently implemented by big companies or big public institutions, such as the Australian Plant Phenomics Facility, the European 
Plant Phenotyping Network, and the United States Department of Agriculture (USDA), but these kinds of platforms are very expensive. Thus it is necessary to develop low-cost and easily manipulated phenotyping tools for their wide adoption in breeding programs [203] to reduce the gap between genomics and phenomics.

Advances in genetic engineering and synthetic biology make it possible to manipulate genes associated with photosynthesis with the aim of improving primary plant production. Several genes of interest for the improvement of photosynthesis and crop yield have been identified and manipulated to modify stomatal conductance, generate better ideotypes, reduce losses from photorespiration and respiration, enhance Rubisco efficiency, and increase sink strength and photoassimilate partitioning into the sink. These studies have been the subject of several reviews [149,150,152,153,204,205]. Despite this, little success has been achieved through genetic modification in improving leaf photosynthesis and WUE [204,205]. Flexas [204] listed some factors that contribute to this limited success: (i) improving gs results in a limited increase in photosynthesis and it is often at the expense of reducing WUE; (ii) there is scarce knowledge of the basis of mesophyll conductance; (iii) improving Rubisco efficiency has failed, and (iv) improving the amount and activity of key Calvin cycle enzymes has been achieved and results in improved photosynthesis. However, these studies do not report the effects on WUE. According to the same author, instead of single-gene/single-trait approaches, multi-gene approaches are necessary to improve photosynthesis and WUE, including those affecting traits like Rubisco, Calvin cycle enzymes, carbohydrate transport, stomatal and mesophyll conductance, and also those related to plant architecture. Perhaps the most ambitious project in this area is the introduction of $\mathrm{C}_{4}$ traits into rice funded by the Bill and Melinda Gates Foundation, which is intended to increase photosynthetic efficiency by $50 \%$, improve nitrogen use efficiency, and double water use efficiency in rice (https://c4rice.com/). Some recent reviews highlight the basis of this work and its advances [206-208].

Despite the broad possibilities of modern molecular and synthetic biology tools for engineering crop photosynthesis, mining of the natural variation in existing germplasm through NGS, QTL, and SNP analyses, together with deeper and more practical phenotype screening, are currently the most feasible approaches for improving plant photosynthesis [150,204].

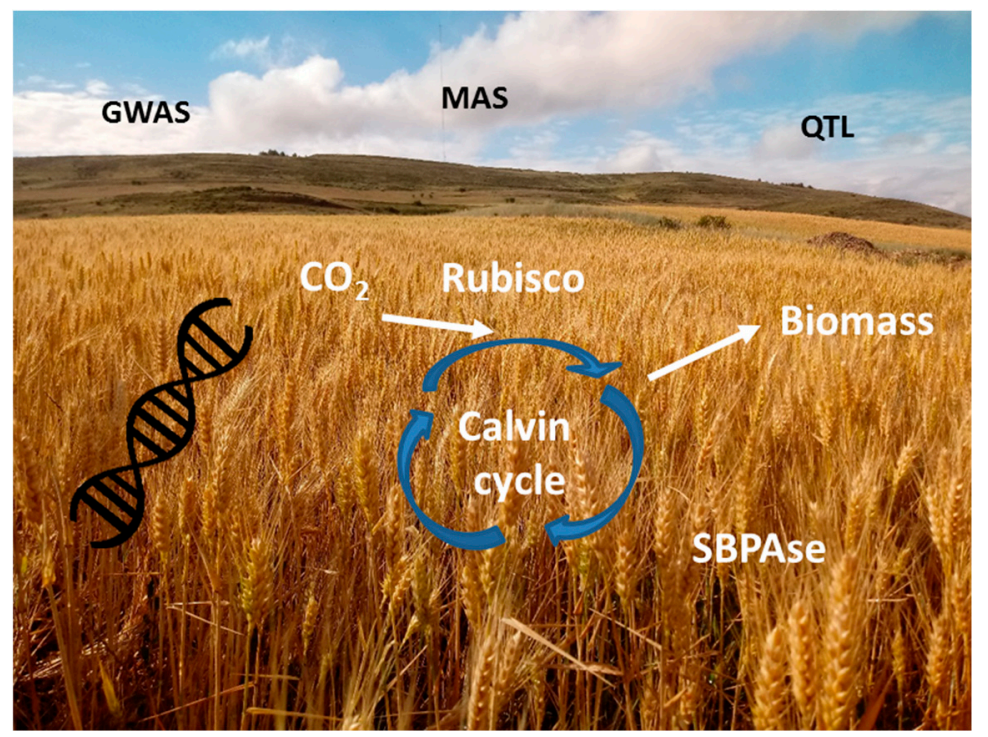

Figure 4. Photosynthesis-based multi-approach crop breeding. Plant photosynthesis, and therefore, growth is determined by multiple regulatory mechanisms. Previous studies have identified traits that may be targeted for modification to improve $\mathrm{CO}_{2}$ assimilation rates and yield. Alongside traditional breeding programs, modern techniques enable the development of synthetic biology and genetic engineering to develop crops that are better adapted to stress. 


\section{Perspectives}

Regardless of the enhancer effect of high $\mathrm{CO}_{2}$ on plant net photosynthesis and productivity, predictions of climate change also involve rises in average temperatures of $2.6^{\circ} \mathrm{C}$ and $4.8^{\circ} \mathrm{C}$ by 2065 and 2100, respectively, and greater climate variability with more frequent periods of drought and heatwaves [209]. It is well established that both high temperature and drought have detrimental effects on photosynthesis and plant production $[210,211]$. When simulated climate change scenarios include elevated atmospheric $\mathrm{CO}_{2}$ concentration alone, plant responses are generally increased in photosynthesis, growth, and yield. However, growth and production may decrease under the future higher atmospheric $\mathrm{CO}_{2}$ concentrations when plants are also subjected to elevated temperature or insufficient water. In fact, significant decreases in yields of rice and wheat have been reported under elevated $\mathrm{CO}_{2}(500 \mathrm{ppm})$ due to an increase in canopy temperature of $1.5-2.0^{\circ} \mathrm{C}$ [212].

Crop production must double by 2050 to meet the predicted production demands of the global population, however, achieving this goal will be a significant challenge for plant breeders. Traditional plant breeding is based on phenotypic selection and subsequent progeny testing, commonly followed by re-selection, which can be a very slow process and often requires time-consuming and costly phenotyping. The understanding of physiologic and molecular mechanisms involved in the response of photosynthetic machinery and plant development under changing environmental conditions could lead to the development of new strategies and tools for enhancing stress tolerance. There is increasing evidence that to achieve a quantum boost to crop yield potential, a major improvement in photosynthetic capacity and/or efficiency will be required. There is also evidence that historic gains in wheat yield potential have been associated with increased photosynthesis. Thus, it is recommended for crop breeding programs to continue working on the improvement of the efficiency of plant $\mathrm{CO}_{2}$ assimilation (through a better $\mathrm{CO}_{2}$ stomatal and/or mesophyll conductance, higher capacity for photosynthetic electron transport and $\mathrm{CO}_{2}$ fixation, and optimized sugar transport and use) and at the same time on the enhancement of the water (WUE) and nutrient use efficiency in preparation for the environmental conditions predicted for the future. Further research is also recommended on plants with delayed senescence (stay-green) since this situation usually maintains the plant photosynthetically active for a longer time leading to an extended period of grain filling.

Author Contributions: Conceptualization I.A.; Writing—review \& editing, I.A., F.M., M.A., D.F., J.G.-T., A.L.G., A.S., D.S., S.B.M. and M.G. All authors have read and agreed to the published version of the manuscript.

Funding: This work was supported by the Spanish Innovation and Universities Ministry (AGL2016-79868-R; PCIN-2017-007).

Conflicts of Interest: The authors declare no conflict of interest.

\section{References}

1. United Nations, Department of Economic and Social Affairs, Population Division. World Population Prospects: The 2017 Revision, Key Findings and Advance Tables. Working Paper No. ESA/P/WP/248. 2017. Available online: https://esa.un.org/unpd/wpp/publications/Files/WPP2017_KeyFindings.pdf (accessed on 16 December 2019).

2. Alexandratos, N.; Bruinsma, J. World Agriculture towards 2030/2050: The 2012 Revision; ESA Working Paper No. 12-03; FAO: Rome, Italy, 2012.

3. IPCC. Contribution of Working Group I to the Third Assessment Report of the Intergovernmental Panel on Climate Change. In Climate Change 2001: The Scientific Basis; Houghton, J.T., Ding, Y., Griggs, D.J., Noguer, M., van der Linden, P.J., Dai, X., Maskell, K., Johnson, C.A., Eds.; Cambridge University Press: Cambridge, UK, 2001; p. 881.

4. IPCC. Contribution of Working Group III to the Fifth Assessment Report of the Intergovernmental Panel on Climate Change. In Climate Change 2014: Mitigation of Climate Change; Edenhofer, O., Pichs-Madruga, R., Sokona, Y., Farahani, E., Kadner, S., Seyboth, K., Adler, A., Baum, I., Brunner, S., Eickemeier, P., et al., Eds.; Cambridge University Press: Cambridge, UK, 2014. 
5. IPCC. Contribution of Working Groups I, II and III to the Fourth Assessment Report of the Intergovernmental Panel on Climate Change. In Climate Change 2007: Synthesis Report; Core Writing Team, Pachauri, R.K., Reisinger, A., Eds.; IPCC: Geneva, Switzerland, 2007; p. 104.

6. Meehl, G.A.; Covey, C.; Delworth, T.; Latif, M.; McAvaney, B.; Mitchell, J.F.B.; Stouffer, R.J.; Taylor, K.E. The WCRP CMIP3 multimodel dataset-A new era in climate change research. Bull. Am. Meteorol. Soc. 2007, 88, 1383-1394. [CrossRef]

7. Arnell, N.W. Climate change and global water resources. Glob. Environ. Chang. 1999, 9, 31-49. [CrossRef]

8. Stone, P. The effects of heat stress on cereal yield and quality. In Crop Responses and Adaptations to Temperature Stress; Basra, A.S., Ed.; Food Products Press: Binghamton, NY, USA, 2001; pp. 243-291.

9. Schlenker, W.; Roberts, M.J. Nonlinear temperature effects indicate severe damages to US crop yields under climate change. Proc. Natl. Acad. Sci. USA 2009, 106, 15594-15598. [CrossRef]

10. Hatfield, J.L.; Prueger, J.H. Temperature extremes: Effect on plant growth and development. Weather Clim. Extrem. 2015, 10, 4-10. [CrossRef]

11. Akter, N.; Islam, M.R. Heat stress effects and management in wheat. A review. Agron. Sustain. Dev. 2017, 37, 37. [CrossRef]

12. Lesk, C.; Rowhani, P.; Ramankutty, N. Influence of extreme weather disasters on global crop production. Nature 2016, 529, 84-87. [CrossRef]

13. Ahmad, Z.; Waraich, E.A.; Akhtar, S.; Anjum, S.; Ahmad, T.; Mahboob, W.; Rizwan, M. Physiological responses of wheat to drought stress and its mitigation approaches. Acta Physiol. Plant. 2018, 40, 80. [CrossRef]

14. Daryanto, S.; Wang, L.; Jacinthe, P.A. Global synthesis of drought effects on cereal, legume, tuber and root crops production: A review. Agric. Water Manag. 2017, 179, 18-33. [CrossRef]

15. Farooq, M.; Wahid, A.; Kobayashi, N.; Fujita, D.; Basra, S. Review article Plant drought stress: Effects, mechanisms and management. Agron. Sustain. Dev. 2009, 29, 185-212. [CrossRef]

16. Lobell, D.B.; Gourdji, S.M. The influence of climate change on global crop productivity. Plant Physiol. 2012, 160, 1686-1697. [CrossRef]

17. Kang, Y.; Khan, S.; Ma, X. Climate change impacts on crop yield, crop water productivity and food security-A review. Prog. Nat. Sci. 2009, 19, 1665-1674. [CrossRef]

18. Morgan, P.B.; Bernacchi, C.J.; Ort, D.R.; Long, S.P. An in vivo analysis of the effect of season-long open-air elevation of ozone to anticipated 2050 levels on photosynthesis in soybean. Plant Physiol. 2004, 135, 2348-2357. [CrossRef] [PubMed]

19. Rivelli, A.R.; James, R.A.; Munns, R.; Condon, A.G. Effect of salinity on water relations and growth of wheat genotypes with contrasting sodium uptake. Funct. Plant Biol. 2002, 29, 1065-1074. [CrossRef]

20. Katerji, N.; Rana, G.; Mastrorilli, M. Modelling of actual evapotranspiration in open top chambers (OTC) at daily and seasonal scale: Multi-Annual validation on soybean in contrasted conditions of water stress and air ozone concentration. Eur. J. Agron. 2010, 33, 218-230. [CrossRef]

21. Hu, Y.; Schmidhalter, U. Drought and salinity: A comparison of their effects on mineral nutrition of plants. J. Plant Nutr. Soil Sci. 2005, 168, 541-549. [CrossRef]

22. Sanchez-Rodrigues, E.; Rubio-Wilhelmi, M.D.; Cervilla, L.M.; Blasco, B.; Rios, J.J.; Leyva, R.; Romero, L.; Ruiz, J.M. Study of the ionome and uptake fluxes in cherry tomato plants under moderate water stress conditions. Plant Soil 2010, 335, 339-347. [CrossRef]

23. Blokhina, O.; Virolainen, E.; Fagerstedt, K.V. Antioxidants, oxidative damage and oxygen deprivation stress: A review. Ann. Bot. 2003, 91, 179-194. [CrossRef]

24. Apel, K.; Hirt, H. Reactive oxygen species: Metabolism, oxidative stress, and signal transduction. Annu. Rev. Plant Biol. 2004, 55, 373-399. [CrossRef]

25. Kangasjärvi, J.; Jaspers, P.; Kollist, H. Signalling and cell death in ozone-exposed plants. Plant Cell Environ. 2005, 28, 1021-1036. [CrossRef]

26. Yamakawa, H.; Hirose, T.; Kuroda, M.; Yamaguchi, T. Comprehensive expression profiling of rice grain filling-related genes under high temperature using DNA microarray. Plant Physiol. 2007, 144, $258-277$. [CrossRef] 
27. Guo, P.G.; Baum, M.; Grando, S.; Ceccarelli, S.; Bai, G.H.; Li, R.H.; vonKorff, M.; Varshney, R.K.; Graner, A.; Valkoun, J. Differentially expressed genes between drought-tolerant and drought-sensitive barley genotypes in response to drought stress during the reproductive stage. J. Exp. Bot. 2009, 60, 3531-3544. [CrossRef] [PubMed]

28. Cornic, G. Drought stress inhibits photosynthesis by decreasing stomatal aperture-Not by affecting ATP synthesis. Trends Plant Sci. 2000, 5, 187-188. [CrossRef]

29. Brestic, M.; Cornic, G.; Fryer, M.J.; Baker, N.R. Does photorespiration protect the photosynthetic apparatus in french bean-leaves from photoinhibition during drought stress. Planta 1995, 196, 450-457. [CrossRef]

30. Gao, Q.; Zhao, P.; Zeng, X.; Cai, X.; Shen, W. A model of stomatal conductance to quantify the relationship between leaf transpiration, microclimate and soil water stress. Plant Cell Environ. 2002, 25, 1373-1381. [CrossRef]

31. Chaves, M.M.; Pereira, J.S.; Maroco, J.; Rodrigues, M.L.; Ricardo, C.P.P.; Osorio, M.L.; Carvalho, I.; Faria, T.; Pinheiro, C. How plants cope with water stress in the field. Photosynthesis and growth. Ann. Bot. 2002, 89, 907-916. [CrossRef]

32. Medrano, H.; Escalona, J.M.; Bota, J.; Gulias, J.; Flexas, J. Regulation of photosynthesis of C-3 plants in response to progressive drought: Stomatal conductance as a reference parameter. Ann. Bot. 2002, 89, 895-905. [CrossRef]

33. Tezara, W.; Mitchell, V.J.; Driscoll, S.D.; Lawlor, D.W. Water stress inhibits plant photosynthesis by decreasing coupling factor and ATP. Nature 1999, 401, 914-917. [CrossRef]

34. Lawlor, D.W.; Cornic, G. Photosynthetic carbon assimilation and associated metabolism in relation to water deficits in higher plants. Plant Cell Environ. 2002, 25, 275-294. [CrossRef]

35. Bita, C.E.; Gerats, T. Plant tolerance to high temperature in a changing environment: Scientific fundamentals and production of heat stress-tolerant crops. Front. Plant Sci. 2013, 4, 273. [CrossRef]

36. Way, D.A. Just the right temperature. Nat. Ecol. Evol. 2019, 3, 718-719. [CrossRef]

37. Berry, J.; Bjorkman, O. Photosynthetic response and adaptation to temperature in higher plants. Annu. Rev. Plant Physiol. 1980, 31, 491-543. [CrossRef]

38. Weis, E.; Berry, J.A. Plants and high temperature stress. Symp. Soc. Exp. Biol. 1988, 42, 329-346. [PubMed]

39. Sharkey, T.D.; Bernachi, C.J.; Farquar, G.D.; Singsaas, E.L. Fitting photosynthetic carbon dioxide response curves for C 3 leaves. Plant Cell Environ. 2007, 30, 1035-1040. [CrossRef] [PubMed]

40. Djanaguiraman, M.; Boyle, D.L.; Welti, R.; Jagadish, S.V.K.; Prasad, P.V.V. Decreased photosynthetic rate under high temperature in wheat is due to lipid desaturation, oxidation, acylation, and damage of organelles. BMC Plant Biol. 2018, 18, 55. [CrossRef] [PubMed]

41. Ismail, A.M.; Hall, A.E. Reproductive-stage heat tolerance, leaf membrane thermostability and plant morphology in cowpea. Crop Sci. 1999, 39, 1762. [CrossRef]

42. Alsajri, F.A.; Singh, B.; Wijewardana, C.; Irby, J.T.; Gao, W.; Reddy, K.R.; Alsajri, F.A.; Singh, B.; Wijewardana, C.; Irby, J.T.; et al. Evaluating soybean cultivars for low- and high-temperature tolerance during the seedling growth stage. Agronomy 2019, 9, 13. [CrossRef]

43. Matsui, T.; Omasa, K. Rice (Oryza sativa L.) cultivars tolerant to high temperature at flowering: Anther characteristics. Ann. Bot. 2002, 89, 683-687. [CrossRef]

44. Asseng, S.; Ewert, F.; Rosenzweig, C.; Jones, J.W.; Hatfield, J.L.; Ruane, A.C.; Boote, K.J.; Thorburn, P.J.; Rotter, R.P.; Cammarano, D.; et al. Uncertainty in simulating wheat yields under climate change. Nat. Clim. Chang. 2013, 3, 827-832. [CrossRef]

45. Gourdji, S.M.; Sibley, A.M.; Lobell, D.B. Global crop exposure to critical high temperatures in the reproductive period: Historical trends and future projections. Environ. Res. Lett. 2013, 8, 24041. [CrossRef]

46. Paupière, M.J.; van Heusden, A.W.; Bovy, A.G. The metabolic basis of pollen thermo-tolerance: Perspectives for breeding. Metabolites 2014, 4, 889. [CrossRef]

47. Wang, X.; Cai, J.; Jiang, D.; Liu, F.; Dai, T.; Cao, W. Pre-anthesis high-temperature acclimation alleviates damage to the flag leaf caused by post-anthesis heat stress in wheat. J. Plant Physiol. 2011, 168, 585-593. [CrossRef] [PubMed]

48. Hay, R.K.M.; Walker, A.J. An Introduction to the Physiology of Crop Yield; Longman Scientific \& Technical: Harlow, UK, 1989; ISBN 047021192X.

49. Mathur, S.; Agrawal, D.; Jajoo, A. Photosynthesis: Response to high temperature stress. J. Photochem. Photobiol. B Biol. 2014, 137, 116-126. [CrossRef] 
50. Kumar Tewari A, A.K.; Tripathy, B.C. Temperature-stress-induced impairment of chlorophyll biosynthetic reactions in cucumber and wheat. Plant Physiol. 1998, 117, 851-858. [CrossRef] [PubMed]

51. Ashraf, M.; Harris, P.J.C. Photosynthesis under stressful environments: An overview. Photosynthetica 2013, 51, 163-190. [CrossRef]

52. Morales, D.; Rodríguez, P.; Dell'Amico, J.; Nicolás, E.; Torrecillas, A.; Sánchez-Blanco, M.J. High-temperature preconditioning and thermal shock imposition affects water relations, gas exchange and root hydraulic conductivity in tomato. Biol. Plant 2004, 47, 203-208. [CrossRef]

53. Crafts-Brandner, S.J.; Law, R.D. Effect of heat stress on the inhibition and recovery of the ribulose-1,5-bisphosphate carboxylase/oxygenase activation state. Planta 2000, 212, 67-74. [CrossRef] [PubMed]

54. Wahid, A.; Gelani, S.; Ashraf, M.; Foolad, M.R. Heat tolerance in plants: An overview. Environ. Exp. Bot. 2007, 61, 199-223. [CrossRef]

55. Yang, Z.; Sinclair, T.R.; Zhu, M.; Messina, C.D.; Cooper, M.; Hammer, G.L. Temperature effect on transpiration response of maize plants to vapour pressure deficit. Environ. Exp. Bot. 2012, 78, 157-162. [CrossRef]

56. Flexas, J.; Ribas-Carbó, M.; Díaz-Espejo, A.; Galmés, J.; Medrano, H. Mesophyll conductance to $\mathrm{CO}_{2}$ : Current knowledge and future prospects. Plant Cell Environ. 2008, 31, 602-621. [CrossRef]

57. Evans, J.R.; Von Caemmerer, S. Carbon dioxide diffusion inside leaves. Plant Physiol. 1996, 110, $339-346$. [CrossRef]

58. Evans, J.R.; Loreto, F. Acquisition and Diffusion of $\mathrm{CO}_{2}$ in Higher Plant Leaves; Springer: Dordrecht, The Netherlands, 2000; pp. 321-351.

59. Walker, B.; Ariza, L.S.; Kaines, S.; Badger, M.R.; Cousins, A.B. Temperature response of in vivo Rubisco kinetics and mesophyll conductance in Arabidopsis thaliana: Comparisons to Nicotiana tabacum. Plant Cell Environ. 2013, 36, 2108-2119. [CrossRef] [PubMed]

60. Bernacchi, C.J.; Portis, A.R.; Nakano, H.; von Caemmerer, S.; Long, S.P. Temperature response of mesophyll conductance. Implications for the determination of Rubisco enzyme kinetics and for limitations to photosynthesis in vivo. Plant Physiol. 2002, 130, 1992. [CrossRef] [PubMed]

61. Warren, C.R. Stand aside stomata, another actor deserves centre stage: The forgotten role of the internal conductance to $\mathrm{CO}_{2}$ transfer. J. Exp. Bot. 2007, 59, 1475-1487. [CrossRef]

62. Gorton, H.L.; Herbert, S.K.; Vogelmann, T.C. Photoacoustic analysis indicates that chloroplast movement does not alter liquid-phase $\mathrm{CO}_{2}$ diffusion in leaves of Alocasia brisbanensis. Plant Physiol. 2003, 132, 1529-1539. [CrossRef] [PubMed]

63. Warren, C.; Dreyer, E. Temperature response of photosynthesis and internal conductance to $\mathrm{CO}_{2}:$ Results from two independent approaches. J. Exp. Bot. 2006, 57, 3057-3067. [CrossRef] [PubMed]

64. Yamori, W.; Suzuki, K.; Noguchi, K.; Nakai, M.; Terashima, I. Effects of Rubisco kinetics and Rubisco activation state on the temperature dependence of the photosynthetic rate in spinach leaves from contrasting growth temperatures. Plant Cell Environ. 2006, 29, 1659-1670. [CrossRef] [PubMed]

65. Von Caemmerer, S.; Evans, J.R. Temperature responses of mesophyll conductance differ greatly between species. Plant Cell Environ. 2015, 38, 629-637. [CrossRef] [PubMed]

66. Flexas, J.; Díaz-Espejo, A. Interspecific differences in temperature response of mesophyll conductance: Food for thought on its origin and regulation. Plant Cell Environ. 2015, 38, 625-628. [CrossRef]

67. Scafaro, A.P.; von Caemmerer, S.; Evans, J.R.; Atwell, B.J. Temperature response of mesophyll conductance in cultivated and wild Oryza species with contrasting mesophyll cell wall thickness. Plant Cell Environ. 2011, 34, 1999-2008. [CrossRef]

68. Fernández-San Millán, A.; Aranjuelo, I.; Douthe, C.; Nadal, M.; Ancín, M.; Larraya, L.; Farran, I.; Flexas, J.; Veramendi, J. Physiological performance of transplastomic tobacco plants overexpressing aquaporin AQP1 in chloroplast membranes. J. Exp. Bot. 2018, 69, 3661-3673. [CrossRef]

69. Dusenge, M.E.; Duarte, A.G.; Way, D.A. Plant carbon metabolism and climate change: Elevated $\mathrm{CO}_{2}$ and temperature impacts on photosynthesis, photorespiration and respiration. New Phytol. 2019, 221, 32-49. [CrossRef] [PubMed]

70. Berry, J.A.; Raison, J.K. Responses of Macrophytes to Temperature. In Physiological Plant Ecology I.; Springer: Berlin/Heidelberg, Germany, 1981; pp. 277-338. 
71. Posch, B.C.; Kariyawasam, B.C.; Bramley, H.; Coast, O.; Richards, R.A.; Reynolds, M.P.; Trethowan, R.; Atkin, O.K. Exploring high temperature responses of photosynthesis and respiration to improve heat tolerance in wheat. J. Exp. Bot. 2019, 70, 5051-5069. [CrossRef] [PubMed]

72. Law, R.D.; Crafts-Brandner, S.J. Inhibition and acclimation of photosynthesis to heat stress is closely correlated with activation of ribulose-1,5-bisphosphate Carboxylase/Oxygenase. Plant Physiol. 1999, 120, 173-182. [CrossRef] [PubMed]

73. Ku, S.-B.; Edwards, G.E. Oxygen Inhibition of Photosynthesis: I. Temperature Dependence and Relation to $\mathrm{O}_{2} / \mathrm{CO}_{2}$ Solubility Ratio. Plant Physiol. 1977, 59, 986-990. [CrossRef] [PubMed]

74. Ku, S.-B.; Edwards, G.E. Oxygen Inhibition of Photosynthesis. Plant Physiol. 1977, 59, 991-999. [CrossRef]

75. Jordan, D.B.; Ogren, W.L. The $\mathrm{CO}_{2} / \mathrm{O}_{2}$ specificity of ribulose 1,5-bisphosphate carboxylase/oxygenase. Planta 1984, 161, 308-313. [CrossRef]

76. Keys, A.J. Biochemistry of photorespiration and the consequences for plant performance. In Plant Carbohydrate Biochemistry; Scientific Publishers: Oxford, UK, 1999; pp. 147-162.

77. Crafts-Brandner, S.J.; Salvucci, M.E. Rubisco activase constrains the photosynthetic potential of leaves at high temperature and $\mathrm{CO}_{2}$. Proc. Natl. Acad. Sci. USA 2000, 97, 13430-13435. [CrossRef]

78. Yamori, W.; von Caemmerer, S. Effect of Rubisco activase deficiency on the temperature response of $\mathrm{CO}_{2}$ assimilation rate and Rubisco activation state: Insights from transgenic tobacco with reduced amounts of Rubisco activase. Plant Physiol. 2009, 151, 2073-2082. [CrossRef]

79. Leuning, R. Temperature dependence of two parameters in a photosynthesis model. Plant Cell Environ. 2002, 25, 1205-1210. [CrossRef]

80. Bernacchi, C.J.; Singsaas, E.L.; Pimentel, C.; Portis, A.R., Jr.; Long, S.P. Improved temperature response functions for models of Rubisco-limited photosynthesis. Plant Cell Environ. 2001, 24, 253-259. [CrossRef]

81. Yamasaki, T.; Yamakawa, T.; Yamane, Y.; Koike, H.; Satoh, K.; Katoh, S. Temperature acclimation of photosynthesis and related changes in photosystem II electron transport in winter wheat. Plant Physiol. 2002, 128, 1087-1097. [CrossRef] [PubMed]

82. Bukhov, N.G.; Wiese, C.; Neimanis, S.; Heber, U. Heat sensitivity of chloroplasts and leaves: Leakage of protons from thylakoids and reversible activation of cyclic electron transport. Photosynth. Res. 1999, 59, 81-93. [CrossRef]

83. Gulen, H.; Eris, A. Effect of heat stress on peroxidase activity and total protein content in strawberry plants. Plant Sci. 2004, 166, 739-744. [CrossRef]

84. Ruelland, E.; Zachowski, A. How plants sense temperature. Environ. Exp. Bot. 2010, 69, 225-232. [CrossRef]

85. Driedonks, N.; Rieu, I.; Vriezen, W.H. Breeding for plant heat tolerance at vegetative and reproductive stages. Plant Reprod. 2016, 29, 67-79. [CrossRef]

86. He, J.; Jiang, Z.; Gao, L.; You, C.; Ma, X.; Wang, X.; Xu, X.; Mo, B.; Chen, X.; Liu, L. Genome-wide transcript and small RNA profiling reveals transcriptomic responses to heat stress. Plant Physiol. 2019, 181, 609-629. [CrossRef]

87. Mondini, L.; Pagnotta, M.A. Sustainable Agriculture Reviews; Lichtfouse, E., Goyal, A., Eds.; Springer International Pubishing: Cham, Switzerland, 2015. [CrossRef]

88. Chaves, M.M.; Flexas, J.; Pinheiro, C. Photosynthesis under drought and salt stress: Regulation mechanisms from whole plant to cell. Ann. Bot. 2009, 103, 551-560. [CrossRef]

89. Taiz, L.; Zeiger, E. Plant Physiology, 5th ed.; Sinauer Associates: Sunderland, MA, USA, 2010; Available online: http://www.sinauer.com/media/wysiwyg/tocs/PlantPhysiology5.pdf (accessed on 16 December 2019).

90. Jamieson, P.D.; Martin, R.J.; Francis, G.S.; Wilson, D.R. Drought effects on biomass production and radiation-use efficiency in barley. Field Crop. Res. 1995, 43, 77-86. [CrossRef]

91. Manickavelu, A.; Nadarajan, N.; Ganesh, S.K.; Gnanamalar, R.P.; Chandra, R. Drought tolerance in rice: Morphological and molecular genetic consideration. Plant Growth Regul. 2006, 50, 121-138. [CrossRef]

92. Marček, T.; Áaron, K.; Végh, B.; Janda, T.; Darko, E. Metabolic response to drought in six winter wheat genotypes. PLoS ONE 2019, 14, e0212411. [CrossRef]

93. Nezhadahmadi, A.; Prodhan, Z.H.; Faruq, G. Drought Tolerance in Wheat. Sci. World J. 2013, $2013,12$. [CrossRef] [PubMed]

94. Flexas, J.; Barón, M.; Bota, J.; Ducruet, J.M.; Gallé, A.; Galmés, J.; Medrano, H. Photosynthesis limitations during water stress acclimation and recovery in the drought-adapted Vitis hybrid Richter-110 (V. berlandieri $\times$ V. rupestris). J. Exp. Bot. 2009, 60, 2361-2377. [CrossRef] [PubMed] 
95. Osakabe, Y.; Osakabe, K.; Shinozaki, K.; Tran, L.-S.P. Response of plants to water stress. Front. Plant Sci. 2014, 5, 86. [CrossRef] [PubMed]

96. Wang, X.; Du, T.; Huang, J.; Peng, S.; Xiong, D. Leaf hydraulic vulnerability triggers the decline in stomatal and mesophyll conductance during drought in rice. J. Exp. Bot. 2018, 69, 4033-4045. [CrossRef] [PubMed]

97. Hatfield, J.L.; Dold, C. Water-Use Efficiency: Advances and Challenges in a Changing Climate. Front. Plant Sci. 2019, 10, 103. [CrossRef]

98. Oweis, T.; Zhang, H.; Pala, M. Water use efficiency of rainfed and irrigated bread wheat in a Mediterranean environment. Agron. J. 2000, 92, 231-238. [CrossRef]

99. Zhang, B.; Li, F.M.; Huang, G.; Cheng, Z.Y.; Zhang, Y. Yield performance of spring wheat improved by regulated deficit irrigation in an arid area. Agric. Water Manag. 2006, 79, 28-42. [CrossRef]

100. Araújo, S.S.; Beebe, S.; Crespi, M.; Delbreil, B.; González, E.M.; Gruber, V.; Patto, M.C.V. Abiotic Stress Responses in Legumes: Strategies Used to Cope with Environmental Challenges. Crit. Rev. Plant Sci. 2015, 34, 237-280. [CrossRef]

101. Tambussi, E.A.; Bort, J.; Araus, J.L. Water use efficiency in C3 cereals under Mediterranean conditions: A review of physiological aspects. Ann. Appl. Biol. 2007, 150, 307-321. [CrossRef]

102. Du, H.; Huang, F.; Wu, N.; Li, X.; Hu, H.; Xiong, L. Integrative Regulation of Drought Escape through ABA-Dependent and -Independent Pathways in Rice. Mol. Plant 2018, 11, 584-597. [CrossRef]

103. Flexas, J.; Bota, J.; Galmés, J.; Medrano, H.; Ribas-Carbó, M. Keeping a positive carbon balance under adverse conditions: Responses of photosynthesis and respiration to water stress. Physiol. Plant. 2006, 127, 343-352. [CrossRef]

104. Hoekstra, F.A.; Golovina, E.A.; Buitink, J. Mechanisms of plant desiccation tolerance. Trends Plant Sci. 2001, 6, 431-438. [CrossRef]

105. Ashraf, M.; Foolad, M.R. Roles of glycine betaine and proline in improving plant abiotic stress resistance. Environ. Exp. Bot. 2007, 59, 206-216. [CrossRef]

106. Slama, A.; Mallek-Maalej, E.; Mohamed, H.B.; Rhim, T.; Radhouane, L. A return to the genetic heritage of durum wheat to cope with drought heightened by climate change. PLoS ONE 2018, 13, e196873. [CrossRef]

107. Morales, F.; Pavlovic, A.; Abadía, A.; Abadía, J. Photosynthesis in poor nutrient soils, in compacted soils, and under drought. In The Leaf: A platform for Performing Photosynthesis; Adams, W.W., III, Terashima, I., Eds.; Springer: Berlin/Heidelberg, Germany, 2018; pp. 371-399.

108. Marschner, H. Mineral Nutrition of Higher Plants; Academic Press: London, UK, 1995.

109. Frydenvang, J.; van Maarschalkerweerd, M.; Carstensen, A.; Mundus, S.; Schmidt, S.B.; Pedas, P.R.; Laursen, K.H.; Schjoerring, J.K.; Husted, S. Sensitive detection of phosphorus deficiency in plants using chlorophyll a fluorescence. Plant Physiol. 2015, 169, 353-361. [CrossRef]

110. Murad, E.; Fisher, W.R. Iron in Soils and Clay Minerals; D Reidel Publishing, Co.: Dordrecht, The Netherlands, 1988.

111. Loeppert, R.H. Reactions of iron and carbonates in calcareous soils. J. Plant Nutr. 1986, 9, 195-215. [CrossRef]

112. Morales, F.; Abadía, A.; Abadía, J. Chlorophyll fluorescence and photon yield of oxygen evolution in iron-deficient sugar beet (Beta vulgaris L.) leaves. Plant Physiol. 1991, 97, 886-893. [CrossRef]

113. Winder, T.L.; Nishio, J. Early iron deficiency stress response in leaves of sugar beet. Plant Physiol. 1995, 108, 1487-1494. [CrossRef]

114. Larbi, A.; Abadía, A.; Abadía, J.; Morales, F. Down co-regulation of light absorption, photochemistry, and carboxylation in Fe-deficient plants growing in different environments. Photosynth. Res. 2006, 89, 113-126. [CrossRef]

115. Polanco, M.C.; Zwiazek, J.J.; Voicu, M.C. Responses of ectomycorrhizal American elm (Ulmus americana) seedlings to salinity and soil compaction. Plant Soil 2008, 308, 189-200. [CrossRef]

116. Li, Z.; Wu, N.; Liu, T.; Chen, H.; Tang, M. Effect of arbuscular mycorrhizal inoculation on water status and photosynthesis of Populus cathayana males and females under water stress. Physiol. Plant. 2015, 155, 192-204. [CrossRef] [PubMed]

117. Lawson, T.; Kramer, D.M.; Raines, C.A. Improving yield by exploiting mechanisms underlying natural variation of photosynthesis. Curr. Opin. Biotechnol. 2012, 23, 215-220. [CrossRef] [PubMed]

118. Reynolds, M.; Foulkes, M.J.; Slafer, G.A.; Berry, P.; Parry, M.A.J.; Snape, J.W.; Angus, W.J. Raising yield potential in wheat. J. Exp. Bot. 2009, 60, 1899-1918. [CrossRef] [PubMed] 
119. Parry, M.A.; Reynolds, M.; Salvucci, M.E.; Raines, C.; Andralojc, P.J.; Zhu, X.G.; Price, G.D.; Condon, A.G.; Furbank, R.T. Raising yield potential of wheat. II. Increasing photosynthetic capacity and efficiency. J. Exp. Bot. 2011, 62, 453-467. [CrossRef] [PubMed]

120. Passioura, J.B. Grain-yield, harvest index, and water-use of wheat. J. Aust. Inst. Agric. Sci. 1977, 43, 117-120.

121. Austin, R.B. Physiological limitations to cereal yields and ways of reducing them by breeding. In Opportunities for Increasing Crop Yields; Hurd, R.G., Biscoe, P.V., Dennis, C., Eds.; Pitman Publishing: London, UK, 1980; pp. 3-19.

122. Austin, R.B.; Bingham, J.; Blackwell, R.D.; Evans, L.T.; Ford, M.A.; Morgan, C.L.; Taylor, M. Genetic improvements in winter-wheat yields since 1900 and associated physiological-changes. J. Agric. Sci. 1980, 94, 675-689. [CrossRef]

123. Foulkes, M.J.; Snape, J.W.; Shearman, V.J.; Reynolds, M.P.; Gaju, O.; Sylvester-Bradley, R. Genetic progress in yield potential in wheat: Recent advances and future prospects. J. Agric. Sci. 2007, 145, 17. [CrossRef]

124. Foulkes, M.J.; Reynolds, M.; Sylvester-Bradley, R. Genetic improvement of grain crops: Yield potential. In Crop Physiology Applications for Genetic Improvement and Agronomy; Sadras, V.O., Calderini, D., Eds.; Elsevier: Amsterdam, The Netherlands, 2009; pp. 235-256.

125. Sinclair, T.R.; Muchow, R.C. Radiation use efficiency. Adv. Agron. 1999, 65, 215-265.

126. Ku, L.X.; Zhao, W.M.; Zhang, J.; Wu, L.C.; Wang, C.L.; Wang, P.A.; Zhang, W.Q.; Chen, Y.H. Quantitative trait loci mapping of leaf angle and leaf orientation value in maize (Zea mays L.). Theor. Appl. Genet. 2010, 121, 951-959. [CrossRef]

127. Zhu, X.G.; Long, S.P.; Ort, D.R. Improving photosynthetic efficiency for greater yield. Annu. Rev. Plant Biol. 2010, 61, 235-261. [CrossRef]

128. Ort, D.R.; Merchant, S.S.; Alric, J.; Barkan, A.; Blankenship, R.E.; Bock, R. Redesigning photosynthesis to sustainably meet global food and bioenergy demand. Proc. Natl. Acad. Sci. USA 2015, 112, 8529-8536. [CrossRef] [PubMed]

129. Duvick, D.N.; Smith, J.S.C.; Cooper, M. Long-term selection in a commercial hybrid corn breeding program: Past, present, and future. Plant Breed. Rev. 2004, 25, 109-151.

130. Duvick, D.N. The contribution of breeding to yield advances in maize (Zea mays L.). Adv. Agron. 2005, 86, 83-145.

131. Lee, E.A.; Tollenaar, M. Physiological basis of successful breeding strategies for maize grain yield. Crop Sci. 2007, 47, S202-S215. [CrossRef]

132. Sakamoto, T.; Morinaka, Y.; Ohnishi, T.; Sunohara, H.; Fujioka, S.; Ueguchi-Tanaka, M.; Mizutani, M.; Sakata, K.; Takatsuto, S.; Yoshida, S.; et al. Erect leaves caused by brassinosteroid deficiency increase biomass production and grain yield in rice. Nat. Biotechnol. 2006, 24, 105-109. [CrossRef] [PubMed]

133. Peng, S.; Khush, G.S.; Virk, P.; Tang, Q.; Zou, Y. Progress in ideotype breeding to increase rice yield potential. Field Crop. Res. 2008, 108, 32-38. [CrossRef]

134. Zhang, Y.; Tang, Q.; Zou, Y.; Li, D.; Qin, J.; Yang, S.; Chen, L.; Xia, B.; Peng, S. Yield potential and radiation use efficiency of 'super' hybrid rice grown under subtropical conditions. Field Crop. Res. 2009, 114, 91-98. [CrossRef]

135. Choudhury, B.J. A sensitivity analysis of the radiation use efficiency for gross photosynthesis and net carbon accumulation by wheat. Agric. For. Meteorol. 2000, 101, 217-234. [CrossRef]

136. Ahmadzadeh, A.; Lee, E.A.; Tollenaar, $\mathrm{M}$. Heterosis for leaf $\mathrm{CO}_{2}$ exchange rate during the grain-filling period in maize. Crop Sci. 2004, 44, 2095-2100. [CrossRef]

137. Vijayalakshmi, K.; Fritz, A.K.; Paulsen, G.M.; Bai, G.; Pandravada, S.; Gill, B.S. Modeling and mapping QTL for senescence-related traits in winter wheat under high temperature. Mol. Breed. 2010, 26, 163-175. [CrossRef]

138. Jordan, D.R.; Hunt, C.H.; Cruickshank, A.W.; Borrell, A.K.; Henzell, R.G. The relationship between the stay-green trait and grain yield in elite sorghum hybrids grown in a range of environments. Crop Sci. 2012, 52, 1153-1161. [CrossRef]

139. Distelfeld, A.; Avni, R.; Fischer, A.M. Senescence, nutrient remobilization, and yield in wheat and barley. J. Exp. Bot. 2014, 65, 3783-3798. [CrossRef] [PubMed]

140. Trachsel, S.; Sun, D.; SanVicente, F.M.; Zheng, H.; Atlin, G.N.; Suarez, E.A.; Babu, R.; Zhang, X. Identification of QTL for early vigor and stay-green conferring tolerance to drought in two connected advanced backcross populations in tropical maize (Zea mays L.). PLoS ONE 2016, 11, e0149636. 
141. Gous, P.W.; Hickey, L.; Christopher, J.T.; Franckowiak, J.; Fox, G.P. Discovery of QTL for stay-green and heat-stress in barley (Hordeum vulgare) grown under simulated abiotic stress conditions. Euphytica 2016, 207, 305-317. [CrossRef]

142. Christopher, J.T.; Christopher, M.J.; Borrell, A.K.; Fletcher, S.; Chenu, K. Stay-green traits to improve wheat adaptation in well-watered and water-limited environments. J. Exp. Bot. 2016, 67, 5159-5172. [CrossRef]

143. Christopher, M.; Chenu, K.; Jennings, R.; Fletcher, S.; Butler, D.; Borrell, A.; Christopher, J. QTL for stay-green traits in wheat in well-watered and water-limited environments. Field Crop. Res. 2018, 217, 32-44. [CrossRef]

144. Luo, P.G.; Deng, K.J.; Hu, X.Y.; Li, L.Q.; Li, X.; Chen, J.B.; Tan, F.Q. Chloroplast ultrastructure regeneration with protection of photosystem II is responsible for the functional 'stay-green' trait in wheat. Plant Cell Environ. 2013, 36, 683-696. [CrossRef]

145. De Simone, V.; Soccio, M.; Borrelli, G.M.; Pastore, D.; Trono, D. Stay-green trait-antioxidant status interrelationship in durum wheat (Triticum durum) flag leaf during post-flowering. J. Plant Res. 2014, 127, 159-171. [CrossRef]

146. Johnson, S.M.; Cummins, I.; Lim, F.L.; Slabas, A.R.; Knight, M.R. Transcriptomic analysis comparing stay-green and senescent Sorghum bicolor lines identifies a role for proline biosynthesis in the stay-green trait. J. Exp. Bot. 2015, 66, 7061-7073. [CrossRef]

147. Cossani, C.M.; Reynolds, M.P. Physiological traits for improving heat tolerance in wheat. Plant Physiol. 2012, 160, 1710-1718. [CrossRef]

148. Niyogi, K.K.; Wolosiuk, R.A.; Malkin, R. Photosynthesis. In Biochemistry and Molecular Biology of Plants; Buchanan, B.B., Gruissem, W., Jones, R.L., Eds.; John Wiley \& Sons: Hoboken, NJ, USA, 2015; pp. 508-562.

149. Sun, J.; Yang, L.; Wang, Y.; Ort, D.R. FACE-ing the global change: Opportunities for improvement in photosynthetic radiation use efficiency and crop yield. Plant Sci. 2009, 177, 511-522. [CrossRef]

150. Furbank, R.T.; Quick, W.P.; Sirault, X.R. Improving photosynthesis and yield potential in cereal crops by targeted genetic manipulation: Prospects, progress and challenges. Field Crop. Res. 2015, 182, 19-29. [CrossRef]

151. Long, S.P.; Marshall-Colon, A.; Zhu, X.G. Meeting the global food demand of the future by engineering crop photosynthesis and yield potential. Cell 2015, 161, 56-66. [CrossRef]

152. Erb, T.J.; Zarzycki, J. Biochemical and synthetic biology approaches to improve photosynthetic $\mathrm{CO}_{2}$-fixation. Curr. Opin. Chem. Biol. 2016, 34, 72-79. [CrossRef]

153. Faralli, M.; Matthews, J.; Lawson, T. Exploiting natural variation and genetic manipulation of stomatal conductance for crop improvement. Curr. Opin. Plant Biol. 2019, 49, 1-7. [CrossRef]

154. Gupta, P.K.; Balyan, H.S.; Gahlaut, V.; Kulwal, P.L. Phenotyping, genetic dissection, and breeding for drought and heat tolerance in common wheat: Status and prospects. Plant Breed. Rev. 2012, 36, 85-147.

155. Farooq, M.; Hussain, M.; Siddique, K.H.M. Drought stress in wheat during flowering and grain-filling periods. CRC Crit. Rev. Plant Sci. 2014, 33, 331-349. [CrossRef]

156. Mackay, T.F.; Stone, E.A.; Ayroles, J.F. The genetics of quantitative traits: Challenges and prospects. Nat. Rev. Genet. 2009, 10, 565. [CrossRef]

157. Gupta, P.; Balyan, H.; Gahlaut, V. QTL analysis for drought tolerance in wheat: Present status and future possibilities. Agronomy 2017, 7, 5. [CrossRef]

158. Lobos, G.A.; Camargo, A.V.; del Pozo, A.; Araus, J.L.; Ortiz, R.; Doonan, J.H. Plant Phenotyping and Phenomics for Plant Breeding. Front. Plant Sci. 2017, 8, 2181. [CrossRef]

159. Singh, B.D.; Singh, A.K. Marker-Assisted Plant Breeding: Principles and Practices; Springer: New Delhi, India, 2015.

160. Adachi, S.; Tsuru, Y.; Nito, N.; Murata, K.; Yamamoto, T.; Ebitani, T.; Ookawa, T.; Yano, M.; Hirasawa, T. Identification and characterization of genomic regions on chromosomes 4 and 8 that control the rate of photosynthesis in rice leaves. J. Exp. Bot. 2011, 62, 1927-1938. [CrossRef]

161. Gu, J.F.; Yin, X.Y.; Struik, P.C.; Stomph, T.J.; Wang, H.Q. Using chromosome introgression lines to map quantitative trait loci for photosynthesis parameters in rice (Oryza sativa L.) leaves under drought and well-watered field conditions. J. Exp. Bot. 2012, 63, 455-469. [CrossRef]

162. Adachi, S.; Yoshikawa, K.; Yamanouchi, U.; Tanabata, T.; Sun, J.; Ookawa, T.; Yamamoto, T.; Sage, R.F.; Hirasawa, T.; Yonemaru, J. Fine mapping of carbon assimilation rate 8, a quantitative trait locus for flag leaf nitrogen content, stomatal conductance and photosynthesis in rice. Front. Plant Sci. 2017, 8, 60. [CrossRef] 
163. Pinto, R.S.; Reynolds, M.P.; Mathews, K.L.; McIntyre, C.L.; Olivares-Villegas, J.J.; Chapman, S.C. Heat and drought adaptive QTL in a wheat population designed to minimize confounding agronomic effects. Theor. Appl. Genet. 2010, 121, 1001-1021. [CrossRef]

164. Aminian, R.; Mohammadi, S.; Hoshmand, S.; Khodombashi, M. Chromosomal analysis of photosynthesis rate and stomatal conductance and their relationships with grain yield in wheat (Triticum aestivum L.) under water-stressed and well-watered conditions. Acta Physiol. Plant 2011, 33, 755-764. [CrossRef]

165. Panio, G.; Motzo, R.; Mastrangelo, A.M.; Marone, D.; Cattivelli, L.; Giunta, F.; De Vita, P. Molecular mapping of stomatal conductance-related traits in durum wheat (Triticum turgidum ssp durum). Ann. Appl. Biol. 2013, 162, 258-270. [CrossRef]

166. Wang, S.G.; Jia, S.S.; Sun, D.Z.; Wang, H.Y.; Dong, F.F.; Ma, H.X.; Jing, R.L.; Ma, G. Genetic basis of traits related to stomatal conductance in wheat cultivars in response to drought stress. Photosynthetica 2015, 53, 299-305. [CrossRef]

167. Liu, L.; Sun, G.; Ren, X.; Li, C.; Sun, D. Identification of QTL underlying physiological and morphological traits of flag leaf in barley. BMC Genet. 2015, 16, 29. [CrossRef]

168. Liu, X.; Fan, Y.; Mak, M.; Babla, M.; Holford, P.; Wang, F.; Chen, G.; Scott, G.; Wang, G.; Shabala, S.; et al. QTLs for stomatal and photosynthetic traits related to salinity tolerance in barley. BMC Genom. 2017, 18, 9. [CrossRef]

169. Lopez, J.R.; Erickson, J.E.; Munoz, P.; Saballos, A.; Felderhoff, T.J.; Vermerris, W. QTLs associated with crown root angle, stomatal conductance, and maturity in Sorghum. Plant Genome 2017, 10, 1-12. [CrossRef]

170. Shearman, V.J.; Scott, R.K.; Foulkes, M.J. Crop physiology and metabolism. Physiological processes associated with wheat yield progress in the UK. Crop Sci. 2005, 185, 175-185.

171. Fischer, R.A.T.; Edmeades, G.O. Breeding and cereal yield progress. Crop Sci. 2010, 50, 85-98. [CrossRef]

172. Mantilla-Perez, M.B.; Salas Fernandez, M.G. Differential manipulation of leaf angle throughout the canopy: Current status and prospects. J. Exp. Bot. 2017, 68, 5699-5717. [CrossRef]

173. Yang, D.; Liu, Y.; Cheng, H.; Chang, L.; Chen, J.; Chai, S.; Li, M. Genetic dissection of flag leaf morphology in wheat (Triticum aestivum L.) under diverse water regimes. BMC Genet. 2016, 17, 94. [CrossRef]

174. Wu, Q.; Chen, Y.; Fu, L.; Zhou, S.; Chen, J.; Zhao, X.; Zhang, D.; Ouyang, S.; Wang, Z.; Li, D.; et al. QTL mapping of flag leaf traits in common wheat using an integrated high-density SSR and SNP genetic linkage map. Euphytica 2016, 208, 337-351. [CrossRef]

175. Liu, K.; Xu, H.; Liu, G.; Guan, P.; Zhou, X.; Peng, H.; Yao, Y.; Ni, Z.; Du, J. QTL mapping of flag leaf-related traits in wheat (Triticum aestivum L.). Theor. Appl. Genet. 2018, 131, 839-849. [CrossRef]

176. Isidro, J.; Knox, R.; Clarke, F.; Singh, A.; De Pauw, R.; Clarke, J.; Somers, D. Quantitative genetic analysis and mapping of leaf angle in durum wheat. Planta 2012, 236, 1713-1723. [CrossRef]

177. Kumar, U.; Joshi, A.K.; Kumari, M.; Paliwal, R.; Kumar, S.; Röder, M.S. Identification of QTLs for stay green trait in wheat (Triticum aestivum L.) in the 'Chirya 3' $\times$ 'Sonalika' population. Euphytica 2010, 174, 437-445. [CrossRef]

178. Shi, S.; Azam, F.I.; Li, H.; Chang, X.; Li, B.; Jing, R. Mapping QTL for stay-green and agronomic traits in wheat under diverse water regimes. Euphytica 2017, 213, 246. [CrossRef]

179. Wang, A.Y.; Li, Y.; Zhang, C.Q. QTL mapping for stay-green in maize (Zea mays). Can. J. Plant Sci. 2012, 92, 249-256. [CrossRef]

180. Almeida, G.D.; Nair, S.; Borém, A.; Cairns, J.; Trachsel, S.; Ribaut, J.M.; Bänziger, M.; Prasanna, B.M.; Crossa, J.; Babu, R. Molecular mapping across three populations reveals a QTL hotspot region on chromosome 3 for secondary traits associated with drought tolerance in tropical maize. Mol. Breed. 2014, 34, 701-715. [CrossRef]

181. Kante, M.; Revilla, P.; de la Fuente, M.; Caicedo, M.; Ordás, B. Stay-green QTLs in temperate elite maize. Euphytica 2016, 207, 463-473. [CrossRef]

182. Yang, Z.; Li, X.; Zhang, N.; Wang, X.; Zhang, Y.; Ding, Y.; Kuai, B.; Huang, X. Mapping and validation of the quantitative trait loci for leaf stay-green-associated parameters in maize. Plant Breed. 2017, 136, 188-196. [CrossRef]

183. Kebede, H.; Subadhi, P.K.; Rosenow, D.T.; Nguyen, H.T. Quantitative trait loci influencing drought tolerance in grain sorghum (Sorghum bicolor L. Moench). Theor. Appl. Genet. 2001, 103, 266-276. [CrossRef]

184. Hausmann, H.I.B.; Mahalakshmi, V.; Reddy, B.V.S.; Scetharama, N.; Harsh, C.T.; Geiger, H.H. QTL mapping of stay-green in two recombinant inbred populations. Theor. Appl. Genet. 2002, 106, 133-142. [CrossRef] 
185. Srinivas, G.; Satish, K.; Madhusudhana, R.; Reddy, R.N.; Mohan, S.M.; Seetharama, N. Identification of quantitative trait loci for agronomically important traits and their association with genic-microsatellite markers in sorghum. Theor. Appl. Genet. 2009, 118, 1439-1454. [CrossRef]

186. Kassahun, B.; Bidinger, F.; Hash, C.; Kuruvinashetti, M. Stay-green expression in early generation Sorghum bicolor (L.) Moench QTL introgression lines. Euphytica 2010, 172, 351-362. [CrossRef]

187. Lim, J.H.; Paek, N.C. Quantitative trait locus mapping and candidate gene analysis for functional stay-green trait in rice. Plant Breed. Biotechnol. 2015, 3, 95-107. [CrossRef]

188. Takai, T.; Kondo, M.; Yano, M.; Yamamoto, T. A quantitative trait locus for chlorophyll content and its association with leaf photosynthesis in rice. Rice 2010, 3, 172-180. [CrossRef]

189. Kumar, S.; Sehgal, S.K.; Kumar, U.; Prasad, P.V.V.; Joshi, A.K.; Gill, B.S. Genomic characterization of drought tolerance-related traits in spring wheat. Euphytica 2012, 186, 265-276. [CrossRef]

190. Xue, D.W.; Chen, M.C.; Zhou, M.X.; Chen, S.; Mao, Y.; Zhang, G.P. QTL analysis of flag leaf in barley (Hordeum vulgare L.) for morphological traits and chlorophyll content. J. Zhejiang Univ. Sci. B 2008, 9, 938-943. [CrossRef]

191. Collard, B.C.Y.; Mackill, D.J. Marker-assisted selection: An approach for precision plant breeding in the twenty-first century. Philos. Trans. R. Soc. B 2008, 363, 557-572. [CrossRef]

192. Wang, B.; Chee, P.W. Application of advanced backcross quantitative trait locus (QTL) analysis in crop improvement. J. Plant Breed. Crop Sci. 2010, 2, 221-232.

193. Pathania, A.; Rialch, N.; Sharma, P.N. Marker-assisted selection in disease resistance breeding: A boon to enhance agriculture production. In Current Developments in Biotechnology and Bioengineering; Dubey, S.K., Pandey, A., Sangwan, R.S., Eds.; Elsevier: Amsterdam, The Netherlands; Oxford, UK; Cambridge, UK, 2017; pp. 187-213.

194. Jiang, G.L. Molecular markers and marker-assisted breeding in plants. In Plant Breeding from Laboratories to Fields; IntechOpen: Rijeka, Croatia, 2013; Available online: https://www.intechopen.com/books/ plant-breeding-from-laboratories-to-fields/molecular-markers-and-marker-assisted-breeding-in-plants (accessed on 16 December 2019). [CrossRef]

195. Bassi, F.M.; Bentley, A.R.; Charmet, G.; Ortiz, R.; Crossa, J. Breeding schemes for the implementation of genomic selection in wheat (Triticum spp.). Plant Sci. 2016, 242, 23-36. [CrossRef]

196. Kang, Y.J.; Lee, T.; Lee, J.; Shim, S.; Jeong, H.; Satyawan, D.; Kim, M.Y.; Lee, S.H. Translational genomics for plant breeding with the genome sequence explosion. Plant Biotechnol. J. 2016, 14, 1057-1069. [CrossRef]

197. Rasheed, A.; Hao, Y.; Xia, X.; Khan, A.; Xu, Y.; Varshney, R.K.; He, Z. Crop breeding chips and genotyping platforms: Progress, challenges, and perspectives. Mol. Plant 2017, 10, 1047-1064. [CrossRef]

198. Heffner, E.L.; Sorrells, M.E.; Jannink, J.L. Genomic selection for crop improvement. Crop Sci. 2009, 49, 1-12. [CrossRef]

199. Jannink, J.L.; Lorenz, A.J.; Iwata, H. Genomic selection in plant breeding: From theory to practice. Brief. Funct. Genom. 2010, 9, 166-177. [CrossRef]

200. Desta, Z.A.; Ortiz, R. Genomic selection: Genome-wide prediction in plant improvement. Trends Plant Sci. 2014, 19, 592-601. [CrossRef]

201. Barabaschi, D.; Tondelli, A.; Desiderio, F.; Volante, A.; Vaccino, P.; Valè, G.; Cattivelli, L. Next generation breeding. Plant Sci. 2016, 242, 3-13. [CrossRef]

202. Furbank, R.T.; Tester, M. Phenomics-technologies to relieve the phenotyping bottleneck. Trends Plant Sci. 2011, 16, 635-644. [CrossRef] [PubMed]

203. Araus, J.L.; Cairns, J.E. Field high-throughput phenotyping: The new crop breeding frontier. Trends Plant Sci. 2014, 19, 52-61. [CrossRef] [PubMed]

204. Flexas, J. Genetic improvement of leaf photosynthesis and intrinsic water use efficiency in C3 plants: Why so much little success? Plant Sci. 2016, 251, 155-161. [CrossRef]

205. Flexas, J.; Díaz-Espejo, A.; Conesa, M.A.; Coopman, R.E.; Douthe, C.; Gago, J.; Gallé, A.; Galmés, J.; Medrano, H.; Ribas-Carbo, M.; et al. Mesophyll conductance to $\mathrm{CO}_{2}$ and Rubisco as targets for improving intrinsic water use efficiency in C3 plants. Plant Cell Environ. 2016, 39, 965-982. [CrossRef]

206. Covshoff, S.; Hibberd, J.M. Integrating C4 photosynthesis into C3 crops to increase yield potential. Curr. Opin. Biotechnol. 2012, 23, 209-214. [CrossRef]

207. Weissmann, S.; Brutnell, T.P. Engineering C4 photosynthetic regulatory networks. Curr. Opin. Biotechnol. 2012, 23, 298-304. [CrossRef] 
208. Wang, P.; Vlad, D.; Langdale, J.A. Finding the genes to build C4 rice. Curr. Opin. Plant Biol. 2016, 31, 44-50. [CrossRef]

209. IPCC. Climate Change: The Physical Science Basis; Cambridge University Press: New York, NY, USA, 2013.

210. Lipiec, J.; Doussan, C.; Nosalewicz, A.; Kondracka, K. Effect of drought and heat stresses on plant growth and yield: A review. Int. Agrophys. 2013, 27, 463-477. [CrossRef]

211. Fahad, S.; Bajwa, A.A.; Nazir, U.; Anjum, S.A.; Farooq, A.; Zohaib, A.; Sadia., S.; Nasim, W.; Adkins, S.; Saud, S.; et al. Crop production under drought and heat stress: Plant responses and management options. Front. Plant Sci. 2017, 8, 1147. [CrossRef]

212. Cai., C.; Yin, X.; He, S.; Jiang, W.; Si, C.; Struik, P.C.; Luo, W.; Li, G.; Xie, Y.; Xiong, Y.; et al. Reponses of wheat and rice to factorial combinations of ambient and elevated $\mathrm{CO}_{2}$ and temperature. Glob. Chang. Biol. 2016, 22, 856-874. [CrossRef]

(C) 2020 by the authors. Licensee MDPI, Basel, Switzerland. This article is an open access article distributed under the terms and conditions of the Creative Commons Attribution (CC BY) license (http://creativecommons.org/licenses/by/4.0/). 